\title{
MOGUĆNOST ZLOUPOTREBE PRAVA U POSTUPKU JAVNOG NADMETANJA ZA PRODAJU NEKRETNINA U IZVRŠNOM POSTUPKU U PRAVU BIH
}

Prof. dr. sc. Meliha Povlakić*

Tahir Herenda, LL.M.**

Nasir Muftić, LL.M.***
UDK: $347.952 .2: 349.418(497.6)$

347.952.2:3.073.512(497.6)

$347.952 .2: 347.235(497.6)$

351.712.2:347.952.2(497.6)

DOI: $10.3935 /$ zpfz.71.34.01

Izvorni znanstveni rad

Primljeno: ožujak 2021.

Reformirano izvršno pravo u Bosni i Hercegovini kao primarni cilj slijedilo je efikasno namirenje vjerovnika. Usprkos tome postoje brojne prepreke koje onemogućavaju ostvarenje tog cilja. U ovom radu autori prezentiraju neke od problema i mogućih zloupotreba procesnih prava u izvršnom pravu Bosne i Hercegovine. Izložena su dva slučaja zloupotrebe prava u postupku izvršenja na nekretninama, koji pak mogu otvoriti put i drugim zloupotrebama procesnih prava. Pri tomu se konstatira nedovoljna razrađenost instituta zloupotrebe procesnih prava u izvršnom postupku i u zakonodavstvu, i u sudskoj praksi i doktrini. Analizirane su sličnosti i razlike u pravima entiteta i pravu Brčko distrikta kada su u pitanju slučajevi zloupotrebe prava koji su predmet ovog rada, ali je i dan osvrt na rješenja u uspo-

* Dr. sc. Meliha Povlakić, profesorica Pravnog fakulteta Univerziteta u Sarajevu, Obala Kulina bana 7, 71000 Sarajevo, Bosna i Hercegovina; m.povlakic@pfsa.unsa.ba; ORCID ID: orcid.org/0000-0002-3735-7543

** Tahir Herenda, LL. M. (CEU), asistent Pravnog fakulteta Univerziteta u Sarajevu, Obala Kulina bana 7, 71000 Sarajevo, Bosna i Hercegovina; t.herenda@pfsa.unsa.ba; ORCID ID: orcid.org/0000-0001-7631-6827

**** Nasir Muftić, LL. M. (CEU), asistent Pravnog fakulteta Univerziteta u Sarajevu, Obala Kulina bana 7, 71000 Sarajevo, Bosna i Hercegovina; n.muftic@pfsa.unsa.ba; ORCID ID: orcid.org/0000-0002-5688-3565 
rednom pravu. Rad je fokusiran na analizu zakonskih rješenja i njihovo tumačenje u svjetlu najnovije sudske prakse u Bosni i Hercegovini i inspiriran je problemima koji su konstatirani analizom recentne sudske prakse. Uočeni problemi često imaju posljedicu da izvršni postupak promaši cilj. Rad se sastoji od dviju cjelina od kojih svaka obraduje jedan problem koji predstavlja zloupotrebu prava. Prva cjelina posvećena je mogućnosti inženjeringa u vezi s najpovoljnijom ponudom prilikom javnog nadmetanja u izvršnom postupku. Druga cjelina obrađuje problem fiktivne ponude za kupovinu nekretnine u postupku javnog nadmetanja i pitanje karaktera dane jamčevine. U radu se daju i prijedlozi za korekciju postojećih rješenja na osnovi dobrih rješenja koja su zastupljena u regiji.

Ključne riječi: izvršni postupak, zloupotreba prava, građansko procesno pravo, javno nadmetanje, izvršenje na nekretninama

\section{UVOD}

Reforma izvršnog prava u Bosni i Hercegovini (dalje u tekstu: BiH) izvršena u entitetima 2003. godine donošenjem entitetskih zakona o izvršnom postupku (Zakon o izvršnom postupku Federacije BiH, dalje u tekstu: ZIP FBiH' ${ }^{1}$; Zakon o izvršnom postupku Republike Srpske, dalje u tekstu: ZIP RS ${ }^{2}$ ), a u Brčko distriktu donošenjem predmetnih zakona u dva navrata 2000. i 2013. godine (Zakon o izvršnom postupku BD BiH, dalje u tekstu: ZIP BD $\mathrm{BiH}^{3}$ ) za prvi je cilj imala povećanje efikasnosti izvršnog postupka. ${ }^{4}$ Velik broj neriješenih izvršnih predmeta može biti jasna indicija da se to nije dogodilo. ${ }^{5}$ Također, o

1 Zakon o izvršnom postupku Federacije BiH, Službene novine FBiH, br. 32/2003, 52/2003, 33/2006, 39/2006, 39/2009, 35/2012 i 46/2016.

2 Zakon o izvršnom postupku Republike Srpske, Službeni glasnik Republike Srpske, br. 5920/2003, 85/2003, 64/2005, 118/2007, 29/2010, 57/2012, 67/2013, 98/2014 i $66 / 2018$.

3 Prvi Zakon o izvršnom postupku u Brčko distriktu BiH donesen je 2000. godine, Službeni glasnik BD BiH, br. 8/2000, 1/2001, 5/2002, 8/2003, 19/2007 i 2/2008. Nakon što je više puta mijenjan, donesen je novi Zakon o izvršnom postupku BD BiH 2013. godine, Službeni glasnik BD BiH, br. 39/2013 i 47/2017. U ovom se radu referira na taj novi zakon.

4 Više o tome Povlakić, M., Die praktischen Probleme des Vollstreckungsrechts - dargestellt am Beispiel von Bosnien und Herzegowina, u: Bundesministerium der Justiz und Deutsche Stiftung für internationale rechtliche Zusammenarbeit e.v. - IRZ (Hrsg.), Konferenzband "Rechtsstaat und Bürger - Anforderungen an eine moderne Justiz", Dubrovnik, 4. - 8. 12. 2002., str. 77 - 86, str. 77.

5 Prema informacijama zaprimljenim od strane Visokog sudskog i tužilačkog vijeća BiH u Rješenju broj 01-07-10-77-114/2019 od 22. 5. 2019. godine, donesenom po zahtjevu za pristup informacijama koji smo uputili za potrebe izrade ovog rada, od ukupnog broja neriješenih predmeta u pravosuđu BiH izvršni referat obuhvaća 
tome svjedoči i velik broj apelacija pred Ustavnim sudom BiH u kojima se utvrđuje povreda prava na pravično suđenje zbog neprovođenja izvršnog postupka u razumnom roku. ${ }^{6}$ Izvršni postupci koji traju i do deset godina nisu rijetkost.

Reforma izvršnog prava u BiH donijela je značajne novine u pogledu izvršenja na nekretninama, a posebno u pogledu provođenja javne prodaje nekretnine, prodajne cijene $u$ javnom nadmetanju i organiziranja ročišta. Jedno od najspornijih mjesta od stupanja na snagu zakona odnosilo se na prodaju nekretnina na trećem ročištu bez ograničenja najniže cijene. ${ }^{7}$ Kritizirano rješenje o prodaji u bescjenje dovelo je do različite prakse sudova, a o tome je u više navrata odlučivao i Ustavni sud BiH. ${ }^{8}$ Dok se ovaj problem nakon više od desetljeća i pol od stupanja zakona o izvršnom postupku, čini se, ipak rješava ${ }^{9}$, u primjeni zakona, i to upravo u svezi s javnim nadmetanjem za prodaju nekretnina, nastali su novi problemi. Nedostatak ili neadekvatnost zakonskih rješenja o javnoj prodaji nekretnina, ali i nesnalaženje sudova u primjeni zakonskih normi, omogućili su zloupotrebe procesnih prava koje ozbiljno ugrožavaju osnovne ciljeve postupka izvršenja. Cilj je ovog rada upozoriti na mogućnosti zloupotreba, analizirati relevantne zakonske odredbe i slučajeve u praksi te predložiti rješenja de lege ferenda kojima bi se ove zloupotrebe izbjegle, pri čemu će poseban oslonac biti usporednopravna rješenja u regiji.

$84 \%$. Broj izvršnih predmeta u pravosuđu BiH iznosi približno 1,8 milijuna, od čega su, prema podacima iz Godišnjeg izvještaja Visokog sudskog i tužilačkog vijeća BiH za 2017. godinu, oni u nekim od najvećih sudova u BiH raspoređeni na sljedeći način: Osnovni sud u Banjoj Luci - 50.549 izvršnih predmeta, Općinski sud u Sarajevu - 900.324 izvršnih predmeta, Općinski sud u Zenici - 113.386 izvršnih predmeta, Osnovni sud u Bijeljini - 148.841 izvršnih predmeta, Općinski sud u Mostaru - 34.833 izvršnih predmeta i Općinski sud u Tuzli - 134.156 izvršnih predmeta.

6 Vidi, inter alia, odluke Ustavnog suda BiH, AP-2734/15 od 14. 10. 2015.; AP-423/15 od 14. 10. 2015.; AP-4007/18 od 12. 3. 2019., AP-444/20 od 5. 5. 2021.

7 O tome više u: Povlakić, M., Prodaja nekretnine na trećem ročištu - da li je rješenje ovog problema na vidiku, Sudska praksa, br. 73, juli - august - septembar 2017., str. 39 - 60; Povlakić, M., Osvrt na dva nova zakonska teksta u Federaciji BiH: Zakon o izmjenama $i$ dopunama Zakona o izvršnom postupku, Zakon o finansijskom poslovanju, Nova pravna revija, br. 2, 2016., str. $4-35$, str. $24-25$.

8 Npr. AP- 4380/13 od 22. 12. 2016. Također, o ovom je pitanju odlučivao višekratno i Europski sud za ljudska prava. Primjera radi u slučajevima Vaskrsić protiv Slovenije (31371/12) od 25. 4. 2017. i Ljaskaj protiv Hrvatske (58630/11) od 20. 12. 2016.

9 U međuvremenu ovaj problem i zloupotrebe povezane s njime postoje samo u Federaciji BiH jer dva druga izvršna zakona ne poznaju više mogućnost prodaje na trećem ročištu bez ograničenja cijene. 
Rad će u fokusu imati odredbe izvršnog postupka o javnoj prodaji koje omogućavaju određene zloupotrebe osoba koje sudjeluju u javnom nadmetanju na štetu drugih sudionika u postupku. Analizirat će se dva moguća slučaja zloupotrebe prava u izvršnom postupku koja su se već pojavila pred sudovima u BiH. Prvi takav tipizirani slučaj odnosi se na situaciju u kojoj je moguće da treće osobe, koje su vjerojatno u dosluhu s izvršenikom, onemogućuju tražitelja izvršenja i sve druge (savjesne) sudionike javne prodaje nekretnine, koja je predmet izvršenja, u njihovim pokušajima da se namire ili da postanu vlasnikom nekretnine tako što manipuliraju ponudama. Činjenjem najpovoljnije (u pravilu nerealno visoke) ponude, koju drugi ponuđači ne mogu nadmašiti, zatvaraju mogućnost efektivnog nadmetanja i postizanja što povoljnije cijene (Poglavlje II). Drugi tipizirani slučaj slijedi iz prvog i s njime je povezan, a odnosi se na to da se daju ponude koje ponuđač nema namjeru poštovati. Odredbe zakona koje reguliraju izvršni postupak u BiH koje su fokusirane na tri najbolja ponuđača omogućavaju da tri osobe u dogovoru s izvršenikom neplaćanjem ponuđene cijene učine neuspješnim prvo, zatim drugo i, na kraju, u Federaciji BiH i treće ročište. Upitno je mora li sud obustaviti postupak i je li jedina alternativa za tražitelja izvršenja predlaganje drugog predmeta izvršenja (Poglavlje III).

Riječ je o procesnopravnim mogućnostima koje zakonski okvir pruža sudionicima izvršnog postupka, koje im, prema našem sudu, omogućavaju ometanje ispunjenja osnovnih ciljeva izvršnog postupka, a to je efikasno namirenje vjerovnika ${ }^{10}$, te njegovo korištenje za ostvarivanje nelegitimnih ciljeva kao što su odugovlačenje postupka s namjerom njegova okončanja bez prodaje nekretnine koja je predmet izvršenja ili stjecanje imovinske koristi bez adekvatne kompenzacije. Navedene dvije zloupotrebe su utoliko opasnije tamo gdje je moguće nekretninu na trećem ročištu prodati bez ograničenja cijene (Federacija $\mathrm{BiH}$ ).

Neostvarivanje svrhe izvršnog postupka te smanjenje njegove efikasnosti može imati različite uzroke, a cilj je ovog rada pokazati kako dvije navedene zloupotrebe mogu utjecati na efikasnost izvršnog postupka jer se vještim inženjeringom javnog nadmetanja može ozbiljno ugroziti ispunjenje svrhe izvršnog postupka.

10 U više judikata Ustavni sud $\mathrm{BiH}$ namirenje vjerovnika smatrao je javnim interesom. Primjera radi predmeti AP-3381/14 od 23. 1. 2015. (t. 40), AP-1086/04 od 2. 12. 2005. (t. 43 i 44). 


\section{INŽENJERING U VEZI S NAJPOVOLJNIJOM PONUDOM}

\section{II.I. Uvod}

Ova zloupotreba vezana je uz proces javnog nadmetanja koji je uređen tako da su nakon što je učinjena određena nerealno visoka ponuda (koju ponuđač u pravilu ni nema namjeru poštovati) ostali sudionici u javnom nadmetanju koji su spremni ponuditi realnu cijenu isključeni iz sudjelovanja u daljnjem tijeku javnog nadmetanja. Potencijal takve zloupotrebe prepoznale su i stranke koje zloupotrebu poduzimaju, ali i sudovi. U ovom dijelu rada bit će riječi o posljedicama te zloupotrebe na efikasnost postupka i prava sudionika u postupku.

\section{II.2. Pravni okvir za usmenu javnu prodaju}

Zakoni o izvršnom postupku u BiH međusobno se mnogo ne razlikuju u dijelu koji se odnosi na reguliranje javnog nadmetanja kao podloge za zloupotrebu prava. ${ }^{11}$ Tamo gdje su razlike prisutne i relevantne za probleme kojima se bavimo u ovom radu, napomena će biti dana u tekstu, dok se svi ostali navodi odnose na sva tri izvršna zakona.

Nekretnine se u izvršnom postupku mogu prodati na usmenoj javnoj prodaji ili neposrednom pogodbom. ${ }^{12}$ Iako je način prodaje nekretnine reguliran u više zakonskih odredaba, ne postoji ni jedna zakonska odredba koja je u potpunosti posvećena reguliranju usmenog javnog nadmetanja; to je uvijek učinjeno u odredbama koje paralelno uređuju i druga pitanja. Zakoni o izvršnom postupku propisuju da se prodaja nekretnina obavlja usmenim javnim nadmetanjem, pri čemu se ročište u pravilu održava u sudskoj zgradi. ${ }^{13}$ Nadmetanje se zaključuje nakon isteka deset minuta neposredno nakon davanja najpovoljnije ponude. Također je propisana mogućnost odgađanja ročišta za nadmetanje i prodaju u slučaju da rješenje o izvršenju nije postalo izvršno. ${ }^{14}$ Uređen je i postupak nakon zaključenja nadmetanja, u skladu s kojim će se utvrditi lista ponuđača koji su ponudili cijenu iznad minimuma i da je nekretnina prodana najpovoljnijem

11 Uitdehaag, J.; Vincken, E., Civil Enforcement in the Western Balkans, Balkans Enforcement Reform Project, Tirana, 2011., str. 78.

12 Neposredna pogodba nije predmet analize ovog dijela rada, pa će se tekst u nastavku odnositi isključivo na usmenu javnu prodaju s fokusom na usmeno javno nadmetanje.

13 Čl. 84. ZIP-a FBiH, čl. 84. ZIP-a RS i čl. 105. ZIP-a BD BiH.

14 Čl. 90. st. 1. ZIP-a FBiH, čl. 90. st. 1. ZIP-a RS i čl. 111 st. 1. ZIP-a BD BiH. 
ponuđaču te da će sud o tome donijeti zaključak za koji će se smatrati da je dostavljen svim osobama kojima se dostavlja te svim sudionicima u nadmetanju istekom trećeg dana od dana njegova isticanja na oglasnoj ploči. ${ }^{15}$

Odredbe kojima je regulirana javna prodaja u BiH sadržavaju brojne praznine, što postaje vidljivo u usporedbi s korespondirajućim normama u izvršnom pravu susjednih država. U vezi s usmenim nadmetanjem nedostaju odredbe o davanju ponude, detaljna pravila o određivanju valjanosti ponude, pravila koja sprječavaju zloupotrebe usmene javne prodaje nekretnina u izvršnom postupku itd. Ni jedan drugi zakon ne propisuje pravila usmene javne prodaje. ${ }^{16}$ Također, to pitanje nije uređeno ni podzakonskim aktima. Zbog toga postoji mogućnost različitog postupanja sudova u postupcima javne prodaje koje vode suci pojedinci ili stručni suradnici.

Pravo Republike Srpske u pogledu načina uređivanja javnog nadmetanja u izvršnom postupku u jednoj se točki razlikuje od prava u FBiH i BD BiH. Odredba iz članka 90. st. 2. ZIP-a RS propisuje da javno nadmetanje počinje objavljivanjem početne cijene. Ako najmanje jedan sudionik prihvati objavljenu cijenu, objavljuje se sljedeća cijena koja je viša i to najmanje za $5 \%$ od prethodne cijene. Taj se postupak ponavlja sve dok posljednja ponuđena cijena ostane neprihvaćena. Na ovaj način pravo Republike Srpske poznaje dražbeni korak (vidi detaljnije II.5.2). Smatramo da pravilo kojim je uspostavljeno ograničenje valjanosti ponude uvjetujući je da bude minimalno $5 \%$ veća od posljednje valjane ne sprječava davanje visokih ponuda koje će odvratiti savjesne sudionike javnog nadmetanja od daljnjeg sudjelovanja, kao što ni ne sprječava da najbolji ponuđači naknadno odustanu kako bi neka druga osoba postala najbolji ponuđač.

U FBiH i BD BiH moguće je zamisliti hipotetičku situaciju u kojoj na usmenoj javnoj prodaji na prvom ročištu, na kojem se nekretnina ne može prodati po cijeni nižoj od polovine utvrđene vrijednosti, jedan od sudionika u nadmetanju odmah na početku nadmetanja ponudi cijenu u visini ili znatno iznad procijenjene vrijednosti. Druge osobe u postupku neće imati interes dalje licitirati. Sud će donijeti pisani zaključak o prodaji nekretnine najpovoljnijem ponuđaču i odrediti mu rok za polaganje cijene. Osobe koje su nudile nerealno visoku cijenu neće u pravilu položiti tu cijenu u određenom roku pa će sud proglasiti prodaju toj osobi nevaljanom i novim zaključkom odrediti da je nekretnina prodana sljedećem najpovoljnijem ponuđaču. Moguće je predvidjeti da će u javnom nadmetanju najbolji ponuđač (koji je ponudio nerealno visoku cijenu) odbiti uplatiti

15 Čl. 90. ZIP-a FBiH, čl. 90. ZIP-a RS i čl. 111. ZIP-a BD BiH.

16 Omanović, S., Glossarium uz novi Zakon o izvršnom postupku Federacije Bosne i Hercegovine, Univerzitet u Sarajevu, Sarajevo, 2005., str. 151. 
cijenu nakon što mu je nekretnina dosuđena kako bi druga osoba s kojom je u dogovoru (koja je drugi najbolji ponuđač) dobila priliku uplatiti ponuđenu cijenu i postati vlasnik. U ovom scenariju najbolji ponuđač je svojom nerealno visokom (fiktivnom) ponudom zapravo onemogućio treće savjesne ponuđače $\mathrm{u}$ nadmetanju te osigurao drugom ponuđaču s kojim je u dogovoru poziciju najpovoljnijeg ponuđača. Zloupotreba u ovoj hipotetičkoj situaciji može se dalje razvijati ako su dvije ili više osoba koje sudjeluju u javnom nadmetanju bile u dogovoru kako bi onemogućile ozbiljnog kupca da kupi nekretninu s ciljem kupovine nekretnine po što je moguće nižoj cijeni ili s ciljem da potpuno spriječe prodaju nekretnine. U hipotetičkoj situaciji lako je pretpostaviti da za ozbiljne kupce ne postoji ekonomska opravdanost da kupe nekretninu za cijenu koja je iznad njezine procijenjene vrijednosti. Na taj se način ozbiljan kupac može isključiti i s drugog ročišta i tako se postupak usmjeriti ka trećem ročištu, na kojem ne postoji ograničenje minimalne cijene (Federacija BiH).

Potrebno je napomenuti da osobe koje su zloupotrijebile nadmetanje i nakon toga nisu uplatile cijenu neće izgubiti položenu jamčevinu u situaciji da dođe do kupovine od strane sljedećeg po redu ponuđača, što takvo postupanje čini još atraktivnijim. O tome više pod III.3.

\section{II.3. Učinci zloupotrebe}

Ova zloupotreba proizvodi direktne učinke na tražitelja izvršenja, izvršenika i treće osobe koje sudjeluju u javnoj prodaji nekretnine u izvršnom postupku.

Za tražitelja izvršenja moguće je nekoliko situacija. Ako je prosječan i razuman tražitelj izvršenja razmišljao o kupovini nekretnine kao o jednoj opciji, on će od te namjere odustati jer neće biti spreman ponuditi više od fiktivne, nerealno visoke ponude. U velikom broju slučajeva zbog niskog stupnja zainteresiranosti za kupovinu nekretnina u izvršnom postupku tražitelj izvršenja je "primoran" kupiti nekretninu i na taj način se namiriti. Zloupotreba postupka javnog nadmetanja davanjem previsokih fiktivnih ponuda će u konačnici onemogućiti svakog razumnog kupca, pa i tražitelja izvršenja, da kupi nekretninu. Tražitelj izvršenja neće namiriti svoju tražbinu na ovaj način. Nadalje, zbog toga što je osnovna posljedica opisane zloupotrebe, a povezano s drugom zloupotrebom, odnosno neuplaćivanjem ponuđene cijene (vidi pod III.2), neuspjelo prvo ročište, prodajna cijena na sljedećem ročištu bit će smanjena i tražitelj izvršenja će biti u opasnosti da tako smanjena prodajna cijena ne bude dovoljna za namirenje njegove tražbine. U tom slučaju mu ne preostaje ništa drugo nego da predloži novi predmet izvršenja, pa da na taj način pokuša namiriti preostali dio tražbine. Određivanja novog predmeta izvršenja ima, međutim, čitav niz 
negativnih posljedica. Tražitelj izvršenja može izgubiti svoj prvenstveni red koji je imao u prvom izvršnom postupku ili svojstvo osiguranog vjerovnika jer na drugom predmetu izvršenja u pravilu nema založno prvo ili neko drugo pravo osiguranja. I tražitelj izvršenja koji ne sudjeluje u javnom nadmetanju može trpjeti iste posljedice opisane zloupotrebe.

Za izvršenika je mogućnost ove zloupotrebe također štetna; na njega se direktno reflektira nemogućnost ili ograničenje namirenja tražitelja izvršenja. Zakoni o izvršnom postupku propisuju redoslijed namirenja, navodeći da se najprije namiruju troškovi izvršnog postupka, zatim potraživanja založnih vjerovnika koja se po redu prvenstva namiruju prije tražitelja izvršenja i onda potraživanja tražitelja izvršenja po čijem je prijedlogu određeno izvršenje. ${ }^{17}$ Ako zbog navedene zloupotrebe nekretnina bude prodana na nekom sljedećem ročištu za manju cijenu i kupi je osoba koja nije tražitelj izvršenja, to u kombinaciji s pravilom o redoslijedu namirenja povećava mogućnost da prodajna cijena ne bude dovoljna za namirenje tražbine tražitelja izvršenja. Posljedica po izvršenika proizlazi iz same okolnosti da će prodajna cijena zbog ove zloupotrebe biti smanjena. Ako se iz tako postignute prodajne cijene tražitelj izvršenja ne uspije namiriti u cijelosti, on ima pravo odrediti drugi predmet i sredstvo izvršenja kako bi namirio preostali iznos duga, čime se imovina izvršenika dodatno umanjuje. Smanjenje prodajne cijene imat će utjecaj na izvršenika i onda kada prodajna cijena može pokriti cjelokupnu tražbinu tražitelja izvršenja jer će višak prodajne cijene koji preostane nakon namirenja tražbine biti nužno manji.

Ta zloupotreba će također utjecati na položaj trećih osoba koje sudjeluju u javnoj prodaji nekretnina u izvršnom postupku. Kako smo ranije naznačili, s obzirom na to da je osnovna posljedica zloupotrebe de facto onemogućavanje nadmetanja zbog previsoke cijene koju jedna od osoba koje djeluju u dogovoru načini u javnoj prodaji, treća će osoba biti onemogućena nadmetati se i po ekonomski opravdanoj cijeni kupiti nekretninu. Učinci zloupotrebe na treće osobe nadilaze konkretne izvršne postupke u kojima se događaju. Oni mogu biti širi i imati učinak na cjelokupni sustav izvršenja na nekretninama. Postojanje zloupotrebe u izvršnom postupku može djelovati destimulirajuće na treće osobe, odvraćajući ih od sudjelovanja u izvršnom postupku zbog spoznaje da nemaju efektivnu pravnu zaštitu u slučaju takve zloupotrebe. Ovo posljedično može dovesti do smanjenja efikasnosti izvršenja na nekretninama ${ }^{18}$, ali i cjelokupnog sustava izvršenja.

17 Čl. 98. ZIP-a FBiH, čl. 98. ZIP-a RS i čl. 119. ZIP-a BD BiH.

$18 \mathrm{U}$ BiH određene banke više uopće ne nude hipotekarne kredite, što može upućivati na nepovjerenje banaka u efikasno izvršenje na nekretninama. 
Osim toga, i ova zloupotreba, kao i ona analizirana u dijelu III., iako ne mora biti nužno poduzeta s tim ciljem, može voditi odugovlačenju izvršnog postupka kao jednom vidu povrede prava na pravično suđenje; pravo na suđenje u razumnom roku smatra se sastavnicom prava na pravično suđenje. ${ }^{19}$

\section{II.4. Zloupotrebe procesnih prava u postupku javnog nadmetanja}

Da bismo odgovorili na pitanje je li institut zabrane zloupotrebe prava adekvatan da spriječi zloupotrebe u postupku javnog nadmetanja, najprije ćemo dati kratak osvrt na institut zloupotrebe procesnih prava (II.4.1.) a nakon toga će se sagledati kako taj institut može spriječiti opisanu zloupotrebu javnog nadmetanja (II.4.2.).

\section{II.4.1. Općenito o zloupotrebi procesnih prava}

Zabrana zloupotrebe prava jedno je od temeljnih načela građanskog prava, ali kao i uvijek kada je riječ o jednom apstraktnom pravnom načelu, velik izazov predstavlja njegova konkretizacija. ${ }^{20}$ Pojam “zloupotreba prava” u općoj teoriji građanskog prava u pravilu se promatra kroz dvije koncepcije, objektivističku i subjektivističku. ${ }^{21}$ Objektivna (finalistička) koncepcija podrazumijeva vršenje prava suprotno njegovu cilju. Subjektivna (intencijska) koncepcija pretpostavlja korištenje prava s namjerom da se drugom prouzroči šteta. ${ }^{22} \mathrm{U}$ materijalnom pravu u BiH, konkretnije u zakonima koji reguliraju obligacione i stvarnopravne

19 Ademović, N.; Marko, J.; Marković, G., Ustavno pravo Bosne i Hercegovine, Fondacija Konrad Adenauer e. V., Predstavništvo u Bosni i Hercegovini, Sarajevo, 2012., str. 263.

20 Vodinelić, V., Građansko pravo, Uvod u građansko pravo i Opšti deo građanskog prava, drugo, izmenjeno i dopunjeno izdanje, Pravni fakultet Univerziteta Union, Beograd, 2014., str. 303.

${ }^{21}$ Doktrina za ove dvije koncepcije upotrebljava i nazive institucionalna i individualna zloupotreba. Vidi u: Vedriš, M.; Klarić, P., Građansko pravo, četvrto izdanje, Narodne novine, Zagreb, 2000., str. 227.

22 Više o zloupotrebi prava vidi u: Marković, M., Zloupotreba prava, Enciklopedija imovinskog prava i prava udruženog rada, Službeni list SFRJ, Beograd, 1978., br. 25; Krneta, S., Povreda “načela poštenja i savjesnosti” kao razlog prestanka subjektivnih gradanskih prava, Godišnjak Pravnog fakulteta u Sarajevu, god. 16. - 17., 1968. - 1969., str. 107 - 128, str. 107 i dalje; Vodinelić, op. cit. u bilj. 20, str. 305 - 318; Nikolić, D., Uvod u sistem građanskog prava, 11. izmenjeno i dopunjeno izdanje, Univerzitet u Novom Sadu, Novi Sad, 2011., str. 372 - 375; Kovačević Kuštrimović, R.; Lazić, M., Uvod u građansko pravo, Punta, Niš, 2008., str. 352 - 358. 
odnose, prihvaćena je modernija i šira objektivna koncepcija zloupotrebe prava. ${ }^{23}$ Institutu zloupotrebe prava u općoj teoriji građanskog prava posvećena je velika pažnja, formulirani su raznoliki, tipizirani slučajevi zloupotrebe prava, pa se pod zloupotrebom podrazumijeva svako prekomjerno, beskorisno, nerazmjerno, neprimjereno ili proturječno vršenje prava. ${ }^{24}$

Prema nekim stajalištima zabrana zloupotrebe prava na isti način vrijedi za sva subjektivna prava ${ }^{25}$, pa bi se opća doktrina o zabrani zloupotrebe prava trebala primijeniti i na zabranu zloupotrebe procesnih prava. U doktrini je zastupljeno i suprotno stajalište prema kojem nije moguće na isti način promatrati zloupotrebu prava npr. u obligacionim odnosima i u sudskom postupku; procesnopravni odnos specifičan je zbog činjenice da je u njega uključena sudska vlast. ${ }^{26}$ Tom se stajalištu priklanjaju i autori ovog rada. Ako dođe do zloupotrebe prava u materijalnopravnim odnosima, posljedice u pravilu trpi samo jedna strana u pravnom odnosu. Ta strana može svoje pravo ostvariti u sudskom postupku, na što svakako nije obavezna. U sudskom postupku je sud taj koji je obavezan spriječiti svaku zloupotrebu prava, i to, prema mišljenju autora, ne samo na zahtjev stranaka već i po službenoj dužnosti, što slijedi direktno iz zakonske norme koja sud obavezuje da spriječi svaku zloupotrebu procesnih prava. Ovo je posljedica činjenice da zloupotreba procesnih ovlaštenja ne ugrožava samo individualne interese druge strane, već i opće interese. Sudski postupak, osim

23 Članak 13. Zakona o obligacionim odnosima FBiH, Službeni list SFRJ, br. 29/1978, 39/1985, 45/1989 i 57/1989, Službeni list RBiH, br. 2/1992, 13/1993 i 1319/1994; Službene novine FBiH, br. 29/2003 i 42/2011 i članak 13. Zakona o obligacionim odnosima RS, Službeni list SFRJ, br. 29/1978, 39/1985, 45/1989 i 57/1989, Službeni glasnik RS, br. 17/1993, 3/1996, 37/2001, 39/2003 i 74/2004 navode: “Zabranjeno je vršenje prava iz obligacionih odnosa protivno cilju zbog koga je ono zakonom ustanovljeno ili priznato." Istovjetne odredbe sadržavaju i članak 4. Zakona o stvarnim pravima FBiH, Službene novine FBiH, br. 66/2013 i 100/2013, članak 4. Zakona o stvarnim pravima RS, Službeni glasnik RS, br. 124/2008, 3/2009, 58/2009, 95/2011, 60/2015 i 18/2016 i članak 3. Zakona o vlasništvu i drugim stvarnim pravima $\mathrm{BD}$ BiH, Službeni glasnik Brčko distrikta BiH, br. 11/2001, 8/2003, 40/2004 i $19 / 2007$.

24 Vodinelić, op. cit. u bilj. 20, str. 306, t. 900; Krneta, S., Subjektivna građanska prava, Enciklopedija imovinskog prava i prava udruženog rada, Službeni list SFRJ, Beograd, 1978., br. 88.

25 Tako Nikolić, op. cit. u bilj. 22, str. 373; Kovačević Kuštrimović; Lazić, op. cit. u bilj. 22, str. 353.

26 Schilken, E., Zivilprozessrecht, 6. Auflage, Vahlen, München, 2010., str. 67, RdNr. 147. 
zaštite prava stranaka, ima cilj i zaštitu pravnog poretka; on vrši određenu socijalnu funkciju čije ostvarenje biva ometano vršenjem zloupotreba prava. ${ }^{27}$

Za razliku od materijalnih propisa, procesni zakoni ne definiraju zloupotrebu prava, već je samo zabranjuju. Tako je u zakonima koji uređuju parnični postupak propisano da su stranke dužne pred sudom govoriti istinu i savjesno se koristiti pravima koja su im priznata zakonima o parničnom postupku ${ }^{28}$ te da je sud dužan onemogućiti svaku zloupotrebu prava koja strankama pripadaju u postupku. ${ }^{29}$ Zabrana zloupotrebe procesnih prava je u zakonima o parničnom postupku definirana zajedno s načelom procesne ekonomije; izvjesno je da zloupotreba prava može voditi i odugovlačenju postupka. Načelo procesne ekonomije podrazumijeva da se u što kraćem vremenu, a sa što manje uloženog rada i što manje materijalnih sredstava, ostvari cilj izvršnog postupka. ${ }^{30}$ Ta dva načela su povezana jer zabrana zloupotrebe procesnih prava može voditi odugovlačenju postupka. Iako Europska konvencija o zaštiti ljudskih prava (dalje u tekstu: EKLJP) propisuje zabranu zloupotrebe prava u članku 17., takva zabrana ne odnosi se na proceduralne garancije u sklopu prava na pravično suđenje jer se smatra da se proceduralna prava ne mogu koristiti za destruktivne aktivnosti. ${ }^{31}$

27 Čalija, B., Zloupotreba prava u građanskom postupku, Godišnjak Pravnog fakulteta u Sarajevu, god. 12, 1964., str. 231 - 258, str. 245; Triva, S.; Dika, M., Građansko parnično procesno pravo, Narodne novine, Zagreb, 2004., str. 5, 201; Janevski, A.; Zoroska Kamilovska, T., Gragansko procesno pravo, knjiga prva, Parnično pravo, vtoro izmeneto i dopulneto izdanie, Pravni fakultet "Justinijan Prvi” vo Skopje, Skopje, 2009., str. 118.

28 Članak 9. Zakona o parničnom postupku FBiH, dalje u tekstu: ZPP FBiH, Službene novine Federacije BiH, br. 53/2003, 7320/2005, 19/2006 i 98/2015; članak 9. Zakona o parničnom postupku RS, dalje u tekstu: ZPP RS, Službeni glasnik Republike Srpske, br. 58/2003, 85/2003, 74/2005, 63/2007 i 105/2008 - odluka US, 45/2009 - odluka US, 4920/2009 i 61/2013; članak 9. Zakona o parničnom postupku BD $\mathrm{BiH}$, dalje u tekstu: ZPP BD BiH, Službeni glasnik BD BiH, br. 28/2018.

Članak 10. st. 2. ZPP-a FBiH, članak 10. st. 2. ZPP-a RS i članak 10. st. 2. ZPP-a BD BiH.

30 O načelu ekonomičnosti postupka vidi u: Mulabdić, S., Građansko procesno pravo, drugo izdanje, Pravni fakultet Univerziteta u Tuzli, Tuzla, 2010., str. 70 - 78; Poznić, B.; Rakić-Vodinelić, V., Građansko procesno pravo, petnaesto izmenjeno i dopunjeno izdanje, Savremena administracija, Beograd, 1999., str. 146 - 147; Huseinbegović, A., Načela civilnog izvršnog postupka, doktorska disertacija, Pravni fakultet, Univerzitet "Džemal Bijedić”, Mostar, 2010., str. 55; Stanković, G.; Račić, R., Parnično procesno pravo, Pravni fakultet Univerziteta u Banjoj Luci, Banja Luka, 2010., str. 210.

31 de Morree, P., Rights and Wrongs under the ECHR: The prohibition of abuse of rights in Article 17 of the European Convention on Human Rights, Intersentia, Cambridge, 2016., str. 80. 
U tom smislu EKLJP, pa samim tim i Europski sud za ljudska prava (dalje u tekstu: ESLJP) ne mogu dati rješenja za sprječavanje te vrste zloupotrebe prava. Ipak, ESLJP je zloupotrebu procesnih prava višekratno sankcionirao odlukama koje su se bavile povredom prava na pravično suđenje u segmentu suđenja $u$ razumnom roku. ${ }^{32}$ Kako je već rečeno, ovdje opisane zloupotrebe prava često vode i do nepotrebnog odugovlačenja izvršnog postupka, a time i do neefikasnog izvršenja sudskih odluka, što je postalo poseban segment prava na pravično suđenje (u segmentu prava na suđenje u razumnom roku). ${ }^{33}$

Odredbe o zloupotrebi procesnih prava sadržane su samo u zakonima koji reguliraju parnični postupak, ali ne i onima koji reguliraju izvanparnični ili izvršni postupak. ${ }^{34} \mathrm{U}$ izvršnom postupku se shodno primjenjuju odredbe zakona koji reguliraju parnični postupak (članak 21. ZIP-a FBiH / ZIP-a RS, članak 23. ZIP-a BD BiH), pa tako i odredbe o zabrani zloupotrebe prava. Ne samo da procesni zakoni ne daju definiciju zloupotrebe procesnih prava, već se ovim pitanjem i doktrina procesnog prava bavi u manjoj mjeri nego opća teorija građanskog prava. Doktrina procesnog prava u regiji se koncentrira, u pravilu, na zloupotrebe u parničnom, a ne u izvršnom postupku ${ }^{35}$; zabrana zloupotrebe procesnih ovlaštenja u izvršnom postupku je pravno pitanje koje "nije izazvalo posebno interesovanje u stručnoj literaturi tako da je ostalo na

32 Pibernik protiv Hrvatske, Aplikacija br. 75139/01, Odluka od 4. 3. 2004.; Omerović protiv Hrvatske, Aplikacija br. 36071/03, Odluka od 1. 6. 2006.; EVT Company protiv Srbije, Aplikacija br. 3102/05, Odluka od 21. 6. 2007.; Bulović protiv Srbije, Aplikacija br. 14145/04, Odluka od 1. 4. 2008.; Atanasović i dr. protiv Makedonije, Aplikacija br. 13886/02, Odluka od 22. 12. 2005.; Jelčić protiv BiH, Aplikacija br. 41183/02, Odluka od 31. 10. 2006.; Muhović i Lekić i dr. protiv BiH, Aplikacija br. 40841/13, Odluka od 15. 9. 2020.; Akeljić i ostali protiv BiH, Aplikacija br. 8039/19, Odluka od 13. 10. 2020.; Burmych protiv Ukrajine, Aplikacija br. 46852/13, Odluka od 12. 10. 2017. itd.

33 Detaljnije Kamiloska-Zoroska, T., Reforme sistema izvršenja u državama regiona - Novi koncepti, kontroverze i dileme, u: Zbornik radova Međunarodnog naučnog skupa Harmonizacija građanskog prava u regionu, Pravni fakultet Univerziteta Istočno Sarajevo, Sarajevo, 2013., str. 447 - 477, str. 448.

34 Omanović, S.; Ruhotina, A., Mjere za suzbijanje zloupotrebe procesnih ovlaštenja u izvršnom postupku, Godišnjak Pravnog fakulteta u Sarajevu, god. LXIII, 2020., str. 487 - 516, str. $488-489$.

35 Tako npr. Čalija, B.; Omanović, S., Građansko procesno pravo, Pravni fakultet Univerziteta u Sarajevu, Sarajevo, 2000., str. 70 i dalje. Također Mulabdić, op. cit. u bilj. 30, str. 76 i dalje; Triva, S.; Belajec, V.; Dika, M., Sudsko izvršno pravo, Informator, Zagreb, 1980., str. 38. U ovom djelu koje inače predstavlja minucioznu analizu izvršnog prava zloupotrebama u izvršnom postupku posvećene su samo 2-3 rečenice i upućeno je na odgovarajuću primjenu pravila parničnog postupka na izvršni. 
marginama naučnog istraživanja i obrade." ${ }^{36}$ Ovo pitanje je obrađeno u pravilu samo u udžbeničkoj literaturi, a i to u pravilu vrlo marginalno ${ }^{37}$, dok su rijetki radovi posvećeni isključivo ovoj temi. ${ }^{38}$ Stoga se na zloupotrebu prava u izvršnom postupku ima primijeniti ono što se odnosi na zloupotrebu procesnih prava općenito, što može predstavljati dodatni problem za izvršne sudove.

Zanemarivanje pitanja zloupotrebe prava specifično u izvršnom postupku nije karakteristično samo za regiju. Primjera radi, ni u njemačkoj doktrini zloupotreba prava u izvršnom postupku nije posebno u fokusu. Njemačka komentatorska literatura, koja u pravilu vrlo minuciozno obrađuje pojedine institute, zloupotrebi procesnih ovlaštenja u izvršnom postupku nije posvetila posebnu pažnju. U nekim komentarima od preko tisuću stranica samo su po jedan ili dva pasusa posvećena pitanju zloupotrebe prava (općenito u građanskom postupku) ${ }^{39}$ ili izvršnom postupku. ${ }^{40}$ Nije drukčije ni u austrijskoj doktrini. ${ }^{41}$

U doktrini procesnog prava ima različitih shvaćanja od kojih neka polaze od veoma širokog pojma zloupotrebe prava u sudskom postupku, dok nasuprot tome postoje i vrlo restriktivna shvaćanja. Prema jednom (širokom) poimanju svaka stranka koja ne nastupa pošteno i savjesno vrši zloupotrebu prava. ${ }^{42}$ Prema nekim autorima zloupotreba procesnih prava jest svako antisocijalno ponašanje, koje ne odgovara ciljevima sudskog postupka kao posebne institucije. ${ }^{43}$ Postoji i shvaćanje prema kojem zloupotreba procesnih ovlaštenja pretpostavlja da je subjekt koji se koristi svojim ovlaštenjem svjestan protupravnosti svojeg procesnog

36 Stanković, G., Zloupotreba prava stranaka u izvršnom postupku, Pravni život, br. 12, 2014., str. 5 - 18, str. 5.

37 Triva; Dika, op. cit. u bilj. 27, str. 201; Janevski; Zoroska Kamilovska, op. cit. u bilj. 27, str. 118 i dalje; Stanković, G., Građansko procesno pravo, IP Justinijan, Beograd, 2004., str. 243; Stanković; Račić, op. cit. u bilj. 30, str. 213. Nešto opširnije kod Račić, R., Izvršno procesno pravo, Pravni fakultet Univerziteta u Banjoj Luci, Banja Luka, 2009., str. 23.

38 Stanković, op. cit. u bilj. 36.; Omanović; Ruhotina, op. cit. u bilj. 34.

39 Tako npr. kod Kern, u: Kern, Ch.; Diehm, D., ZPO Zivilprozessordnung, Kommentar, 2., neu bearbeitete und wesentlich erweiterte Ausgabe, Erich Schmidt Verlag, Berlin, 2020., ZPO Einleitung, str. 8, RdNr. 17 - 19.

40 Tako su kod Zöller, R., ZPO Zivilprozesordnung, 29. Auflage, Verlag Dr. Otto Schmidt, Köln, 2012., Vollstreckung, § 767., RdNr. 12. navedeni samo pojedini primjeri iz prakse.

41 Tako u Rechberger, W.; Oberhammer, P., Executionsrecht, 3. Auflage, WUV Universitätsverlag, Wien, 2002., načelo zloupotrebe prava nije niti spomenuto među načelima izvršnog postupka.

42 Poznić; Rakić-Vodinelić, op. cit. u bilj. 30, str. 143.

43 Tako Čalija; Omanović, op. cit. u bilj. 35, str. 70; Stanković, op. cit. u bilj. 36, str. 6. 
ponašanja, pa ga namjerno i uz to poduzima ${ }^{44}$ Prema komentatorima entitetskih zakona o parničnom postupku načelo zabrane zloupotrebe procesnih prava podrazumijeva obavezu suda da utvrdi i otkloni svaku procesnu radnju stranke koja je svjesno poduzeta radi šikaniranja suda i protivne strane. ${ }^{45}$ Smatramo da je ovim dana preuska definicija zloupotrebe prava. Njome je obuhvaćena samo šikana, dok je pojam zloupotrebe prava u pozitivnom materijalnom pravu, ali i općenito u modernoj doktrini, mnogo širi. Ima stajališta koja su kombinacija individualnog koncepta zloupotrebe prava, koji se bazira na namjeri nanošenja štete drugima, i institucionalnog (ponašanje suprotno dobrim običajima, načelu savjesnosti i poštenja). ${ }^{46}$ Prema nekim autorima pouzdan indikator da je riječ o zabrani zloupotrebe procesnih prava jest nedostatak opravdanog pravnog interesa za poduzimanje određene radnje ili za određeno postupanje. ${ }^{47}$

Usprkos različitim objašnjenjima zloupotrebe prava doktrina procesnog prava u regiji ${ }^{48}$, kao i opće teorija građanskog prava, izgradila je čitav niz tipiziranih ponašanja koja je moguće smatrati zloupotrebom prava (šikanozno ponašanje, vršenje prava bez opravdanog interesa, vršenje prava suprotno cilju zbog kojeg je ustanovljeno, nesavjesno vršenje prava, neprimjereno vršenje prava, proturječno vršenje prava - venire contra factum proprium).$^{49}$

44 Keča, R., Građansko procesno pravo, Priručnici za polaganje pravosudnog ispita, Knjiga 7, Pravni fakultet Univerziteta u Beogradu, Javno preduzeće Službeni glasnik, Beograd, 2012., str. 155. Ovaj koncept vidimo kritično: osoba koja vrši zloupotrebu ne ponaša se primarno protupravno jer ona vrši svoje pravo. Ipak, pravni poredak u pravilu takvo ponašanje zabranjuje. Tako Kovačević Kuštrimović; Lazić, op. cit. u bilj. 22, str. 352. Još prikladnije stajalište da se takvom ponašanju uskraćuje pravna zaštita; pravna zaštita može biti uskraćena i nečemu što je dopušteno. Tako Vodinelić, op. cit. u bilj. 20, str. 305, t. 897.

45 Kulenović, Z.; Mikulić, S.; Milišić-Veličkovski, S.; Stanišić, J.; Vučina, D., Komentari Zakona o parničnom postupku u Federaciji Bosne i Hercegovine i Republici Srpskoj, Vijeće Evrope i Evropska komisija, Sarajevo, 2005., str. 22.

46 Triva; Dika, op. cit. u bilj. 27, str. 201.

47 Stanković, op. cit. u bilj. 36, str. 10.

48 Iscrpan pregled stajališta o zloupotrebi prava u parničnom postupku na području bivše SFRJ vidi u: Rakočević, M., Bona fides u parničnom postupku, Zbornik radova Pravnog fakulteta u Splitu, god. 55, br. 4, 2018., str. 771 - 789, str. 777 i dalje.

49 Vidi u: Rakočević, op. cit. u bilj. 48, str. 783 - 788. Tako i u njemačkoj doktrini Schilken, op. cit. u bilj. 26, str. 68 - 69. Više o ustanovi venire contra factum proprium vidi u: Stojanović, D., Savjesnost i poštenje, Enciklopedija imovinskog prava i prava udruženog rada, Službeni list SFRJ, Beograd, 1978., br. 63 - 81. 
Sve bi navedeno sudovi morali imati u vidu kada odlučuju o tome zloupotrebljava li neka stranka procesna ovlaštenja u izvršnom postupku, što je izuzetno zahtjevna zadaća za sudove.

Oslanjanje samo na primjenu načela zabrane zloupotrebe prava značilo bi prepuštanje regulacije izvršnog postupka ex post facto regulaciji jer bi sud u svakom konkretnom slučaju bio obavezan procjenjivati zloupotrebljavaju li određeni sudionici u postupku svoja subjektivna prava. To rješenje je u prvom redu ograničeno zbog toga što zahtijeva dodatno vrijeme koje sud ili stručni suradnik treba posvetiti pojedinom predmetu. Budući da su izvršni odjeli sudova u Bosni i Hercegovini opterećeni velikim brojem predmeta, ova zaštita može biti neadekvatna. ${ }^{50}$

\section{II.4.2. Može li primjena načela zabrane zloupotrebe procesnih prava spriječiti zloupotrebu javnog nadmetanja?}

Kada je u pitanju zloupotreba koja se ovdje analizira, temeljni nedostatak principa zabrane zloupotrebe prava je u tome što je jako teško utvrditi postojanje zloupotrebe. Ne postoje egzaktna pravila na temelju kojih sud može procijeniti da je pojedini sudionik u postupku javne prodaje savjestan ili nije. U jednoj svojoj odluci AP-1 154/1451 Ustavni sud BiH (o ovoj odluci više pod III.5.) potiče sudove da zabrane zloupotrebu prava, ali ne daje nikakve parametre za to. Prema stajalištu Ustavnog suda BiH sud se u izvršnom postupku ima pravo pozvati na načelo zabrane zloupotrebe prava na temelju supsidijarne primjene Zakona o parničnom postupku, koje obavezuje sud da onemogući svaku zloupotrebu prava koja strankama pripadaju u postupku. ${ }^{52}$

Vjerojatno bi prima facie najjasniji indikator ove zloupotrebe bila situacija u kojoj bi netko od sudionika u postupku javnog nadmetanja načinio ponudu koja je puno viša od prethodnih ponuda, pa čak i od procijenjene vrijednosti. Postavlja se pitanje što bi sud u takvoj situaciji trebao učiniti. Ako je ponuđena

50 Iz informacija koje smo zaprimili od Visokog sudskog i tužilačkog vijeća BiH (vidi bilj. 2), prosječna opterećenost sudaca i stručnih suradnika koji su u 2018. godini raspoređeni u izvršno odjeljenje gore navedenih sudova iznosila je 107 \%. Osobito je zapanjujući podatak da su tri stručna suradnika, koja su u 2018. godini radila u Općinskom sudu u Sarajevu, u Odjeljenju za vjerodostojnu ispravu, u toj godini ostvarila veoma visoke vrijednosti godišnje norme, i to: 450 \%, 396 \% i $609 \%$.

51 U dijelu ovog rada koji govori o utjecaju te odluke Ustavnog suda na zloupotrebu kroz fiktivne ponude izložen je osvrt na njezine nedostatke koji onemogućavaju da djeluje kao uputa za buduće postupanje sudova.

52 Članak 21. ZIP-a FBiH, članak 21. ZIP-a RS i članak 23. ZIP-a BD BiH. 
cijena znatno viša od procijenjene vrijednosti, na temelju čega će sud utvrditi da ponuđač nije savjestan, da takva kupovina ne služi njegovu opravdanom interesu? Čak i ako je ponuđena cijena znatno viša od procijenjene vrijednosti nekretnine, nije nemoguće tvrditi da je ponuđač npr. predvidio rast cijena nekretnina, pa smatra da će moći ostvariti zaradu ili da ima neki subjektivni razlog za kupovinu nekretnine koji ne mora biti poznat drugima. Zakoni o izvršnom postupku daju pravo svakom pojedincu koji položi jamčevinu za sudjelovanje u javnoj prodaji. Ako zaključkom bude utvrđeno da je nekretnina prodana određenoj osobi kao najpovoljnijem ponuđaču, a ona ne položi cijenu u određenom roku, smatramo da ni tada ne postoji prostor za prima facie sumnju na zloupotrebu. ${ }^{53}$ Također, jako bi teško bilo dokazati postojanje dogovora između osoba koje su izvršile zloupotrebu. Ako se te osobe pripreme tako da sud i drugi sudionici u postupku ne znaju za njihovo koordinirano djelovanje, teško je zamisliti mogućnost utvrđivanja zloupotrebe prava bez izuzetnih napora kojima bi sud i drugi sudionici javnog nadmetanja bili izloženi.

Činjenična pozadina u prethodno navedenom slučaju u kojem je odlučivao Ustavni sud BiH i utvrdio zloupotrebu prava bila je specifična jer su postojali jasni dokazi o koordiniranom djelovanju ponuđača i njihovoj platnoj nesposobnosti. Također, u tom su predmetu sumnju u postojanje zloupotrebe izrazili tražitelji izvršenja, a ne sud samoinicijativno; sud ove podatke neće u pravilu ni imati. Smatramo da u velikom broju situacija u kojima će se problem koji razmatramo javiti neće postojati tako jasni dokazi kakvi su bili prisutni u ovom predmetu (npr. ako osobe koje vrše zloupotrebu nisu poznate ni jednom od sudionika javnog nadmetanja). Uza sve to, kao što smo ranije naveli, ne postoji prostor za prima facie sumnju na zloupotrebu ako osoba kojoj je dosuđena nekretnina ne položi cijenu u propisanom roku. Osim toga, u velikom broju slučajeva, sud bi mogao biti svjestan te zloupotrebe tek nakon što se ona odigrala. Sud može djelovati samo represivno, pri čemu nisu zakonom precizno definirane represivne mjere u slučaju zloupotrebe prava u izvršnom postupku. ${ }^{54}$

53 Moguće je npr. da je ponuđač očekivao prihode koje nije ostvario u predviđenom roku.

54 Kao represivne mjere za sankciju zloupotrebe prava doktrina navodi prije svega oduzimanje pravnog značaja nekoj formalno pravno valjanoj procesnoj radnji. U tom smislu, Zuglia, S., Građanski parnični postupak FNRJ, Školska knjiga, Zagreb, 1957., str. 122; Keča, R., Građansko procesno pravo, 2. izmenjeno i dopunjeno izdanje, Pravni fakultet Univerziteta u Beogradu i Službeni glasnik, Beograd, 2010., str. 137; Omanović; Ruhotina, op. cit. u bilj. 34, str. 505. Osim toga, kao represivne mjere doktrina navodi nadoknadu troškova izazvanih abuzivnom radnjom, novčanu kaznu i naknadu štete. Tako Čalija; Omanović, op. cit. u bilj. 35, str. 73; Stanković, 
Zbog svega navedenog, postojeći institut zloupotrebe prava, doktrinarno neupitan, nije potpuno podoban alat za borbu sa specifičnim vidom zloupotrebe koji se analizira u ovom dijelu rada (a to će biti slučaj i s drugom zloupotrebom, koja se analizira u dijelu III.). Da bi to postao, potrebno je zakonski urediti njegove granice i načine na koje se sud njime može koristiti, što bi ga učinilo efikasnim u borbi protiv ove zloupotrebe. Složili bismo se sa stavom da mora postojati određeni definicijski minimum koji postavlja zakonodavac. ${ }^{55}$ To je prvi korak u sprječavanju zloupotrebe. Međutim, nužno je biti svjestan limitiranosti zakonodavca da precizno odredi što bi bila zloupotreba prava u svakom konkretnom slučaju, stoga su ipak sudovi ti koji ovdje nose teret; borba protiv zloupotrebe prava u izvršnom postupku zadatak je i zakonodavca i suda. ${ }^{56}$

\section{II.5. Prijedlozi de lege ferenda}

Efikasno sprječavanje zloupotrebe pravila o javnom nadmetanju, kako je i prethodno rečeno, nije moguće prepustiti samo sudu. Adekvatno sredstvo koje može spriječiti navedenu zloupotrebu javnog nadmetanja jest uređenje javnog nadmetanja u okviru zakonskog ili podzakonskog teksta, što bi imalo karakter preventivne mjere za suzbijanje ove zloupotrebe. Moguće su dvije zakonodavne intervencije kojima bi se zloupotreba javnog nadmetanja stavljanjem nerealno visoke ponude mogla onemogućiti - mogućnost stavljanja ponuda koje nisu najpovoljnije i uvođenje dražbenog koraka. Obje će biti elaborirane u nastavku.

\section{II.5.I. Mogućnost stavljanja ponuda koje nisu najpovoljnije}

Prva mogućnost suočavanja s ovim problemom bila bi uvođenje mogućnosti slobodnog stavljanja ponuda, pri čemu svaka sljedeća ne bi morala biti viša od prethodne ponude. Na taj način bi se spriječila mogućnost da u prvoj fazi osoba koja je dala nerealno visoku ponudu onemogući stavljanje realnih i ozbiljnih ponuda, a kasnije, u sljedećoj fazi, da odbijanjem polaganja cijene spriječi prodaju nekretnine na određenom ročištu ili omogući da određena osoba postane vlasnik za nižu cijenu na nekom kasnijem ročištu za prodaju.

op. cit. u bilj. 36, str. 15 - 18; Janevski; Zoroska Kamilovska, op. cit. u bilj. 27, str.

121 - 122; Omanović; Ruhotina, op. cit. u bilj. 34, str. 505.

55 Rakočević, op. cit. u bilj. 48, str. 776.

56 Tako Stanković, op. cit. u bilj. 36, str. 6; Marković, op. cit. u bilj. 22, str. 66. 
Kada bi se omogućilo slobodno nadmetanje, u svakoj bi se fazi mogla dati ponuda nevezana za njezinu visinu. U konačnici bi postojao određeni broj ponuda, a među njima bi bile i realne, ozbiljno dane ponude. Na taj način bi se omogućilo da svaki sudionik javnog nadmetanja može načiniti ponudu neovisno o iznosu ponude koju su učinile osobe prije njega i koje su ovom zloupotrebom željele onemogućiti kupovinu nekretnine ili omogućiti kupovinu od strane određene osobe.

Zakoni o izvršnom postupku u BiH propisuju da se nadmetanje zaključuje nakon isteka deset minuta neposredno nakon stavljanja najpovoljnije ponude, nakon čega se utvrđuje lista ponuđača koji su ponudili cijenu iznad minimuma, kao i da je nekretnina prodana najpovoljnijem ponuđaču ako su ispunjeni ostali uvjeti. ${ }^{57}$ Zbog toga ne bi bilo moguće tumačenje prema kojem je dozvoljeno činjenje ponuda koje nisu povoljnije od prethodno dane ponude. Ono možda ne bi bilo eksplicitno u suprotnosti s postojećim zakonskim uređenjem ovog pitanja (izuzetak je Republika Srpska, članak 90. st. 2. ZIP-a RS). Autori su svjesni da nije u prirodi postupka javnog nadmetanja da se on može kretati i u suprotnom smjeru, ali bi ovakvo neortodoksno rješenje oduzelo oštricu navedenoj zloupotrebi prava u izvršnom postupku. Stavljanje nerealno visokih ponuda ne bi imalo u konačnici nikakav efekt jer bi se mogle stavljati i razumne ponude (iznad zakonskog minimuma za pojedino ročište), a one bi se kasnije uzele u obzir kada ponuđači nerealno visoke cijene ne izvrše uplatu.

Ono što ovdje ostaje neriješeno jest mehanizam kako zaključiti nadmetanje. Postojeće rješenje predviđa da je to deset minuta nakon što je stavljena najpovoljnija ponuda, a novo rješenje bi moglo biti deset minuta nakon što na tri puta ponovljeni poziv ne bude stavljena nova ponuda.

Ipak, ovo rješenje nije prisutno u $\mathrm{BiH}$, ali ni u propisima država u regiji, iako bi moglo imati određenih prednosti.

\section{II.5.2. Uvođenje dražbenog koraka}

Druga preventivna mjera za sprječavanje ove zloupotrebe podrazumijeva ograničavanje prava ponuđača da samostalno odredi iznos ponude koju je spreman staviti propisivanjem određenog mehanizma koji po unaprijed određenim pravilima utvrđuje moguću visinu svake ponude koja se daje u okviru javnog nadmetanja. Ovaj institut poznat je pod nazivom dražbeni korak. ${ }^{58}$ Dražbeni

57 Članak 90. ZIP-a FBiH, članak 90. ZIP-a RS i članak 111. ZIP-a BD BiH.

58 Termin "dražbeni korak" u ovom se radu koristi kao generički termin koji opisuje sve institute u okviru javnog nadmetanja u izvršnom postupku koji ograničavaju 
korak $\mathrm{u}$ određenim je formama prisutan u pravu zemalja regije (v. dalje u tekstu). Uvođenjem dražbenog koraka ova zloupotreba može biti ograničena ili onemogućena jer fiktivni ponuđač ne bi bio u mogućnosti načiniti tako visoku ponudu koja bi de facto onemogućila sudjelovanje drugih ponuđača.

Uvođenje dražbenog koraka u okviru javnog nadmetanja u izvršnom postupku u BiH već je ranije predlagano u literaturi. Komentatori zakona o izvršnom postupku FBiH i RS još su 2005. godine primijetili pravne praznine u uređenju javnog nadmetanja i predložili da osoba koja rukovodi nadmetanjem (sudac, stručni suradnik) po određenim pravilima podiže cijenu dok se ne dobije najpovoljnija ponuda, npr. čim jedan sudionik prihvati objavljenu cijenu, da objavljuje sljedeću, koja je u određenom postotku viša od prethodne. ${ }^{59}$ U Republici Srpskoj naknadnim je izmjenama ZIP-a RS prihvaćena ta ideja i uveden dražbeni korak. Kako je ranije navedeno, članak 90. st. 2. ZIP-a RS propisuje da ako najmanje jedan sudionik prihvati objavljenu cijenu, objavljuje se sljedeća cijena koja je viša, i to najmanje za $5 \%$, od prethodne cijene.

Postupak prodaje nekretnina u izvršnom postupku u Hrvatskoj provodi Financijska agencija (FINA). Za razliku od BiH, u Hrvatskoj se prodaja nekretnina u izvršnom postupku provodi elektroničkim javnim nadmetanjem, u skladu s člankom 97. Ovršnog zakona (dalje u tekstu: OZ) ${ }^{60}$ Zapravo, Hrvatska se prema tome što se javna prodaja u izvršnom postupku provodi elektroničkim putem razlikuje i od velikog broja država u Europi uopće. ${ }^{61}$ Pravilnik o načinu i postupku provedbe prodaje nekretnina i pokretnina u ovršnom postupku ${ }^{62}$ (dalje u tekstu: Pravilnik) razrađuje odredbe OZ-a koje govore o javnoj prodaji nekretnina.

U članku 19. Pravilnika dražbeni korak definiran je kao korak povećanja cijene za koji ponuđač može dati ponudu u odnosu na iznos minimalne cijene za koju se predmet prodaje može prodati ili na iznos zadnje valjane ponude.

pravo ponuđača da slobodno načini ponudu kroz utvrđivanje pravila koja jasno utvrđuju visinu svake ponude koja se može dati.

59 Povlakić, M., u: Daupović, A.; Obradović, R.; Povlakić, M.; Zaćiragić, F.; Živanović, M. (dalje u tekstu: Daupović et al.), Komentari Zakona o izvršnom postupku u Federaciji Bosne i Hercegovine i Republici Srpskoj, Vijeće Evrope i Evropska komisija, Sarajevo, 2005., str. 363.

60 Ovršni zakon Republike Hrvatske, Narodne novine, br. 112/2012, 25/2013, 93/2014, 55/2016 i 73/2017.

61 Lista zemalja koje poznaju elektroničku dražbu dostupna je na: https://e-justice. europa.eu/content_judicial_auctions-473-en.do (15. lipnja 2021.).

62 Pravilnik o načinu i postupku provedbe prodaje nekretnina i pokretnina u ovršnom postupku, Narodne novine, br. 93/2014 i 1/2019. 
Ponuđač može odabrati između unaprijed ponuđenih iznosa ponude koje mu nudi sistem elektroničkog javnog nadmetanja, a koji zavisi od utvrđene vrijednosti predmeta prodaje. Iznos dražbenog koraka određuje se prema utvrđenoj vrijednosti predmeta prodaje, koje Pravilnik uređuje prilično detaljno. ${ }^{63}$ Prema prvotnom je rješenju maksimalni broj dražbenih koraka za koje je ponuđač mogao povećati ponudu bio jednak zbroju tri dražbena koraka. Dana 1. travnja 2019. stupile su na snagu izmjene Pravilnika koje su, među ostalim, promijenile i odredbe članka 21. Sada je dozvoljeno povećanje ponude i do zbroja deset dražbenih koraka. FINA je, osvrćući se na izmjene Pravilnika, u jednom medijskom obraćanju navela sljedeće: "Jedna od izmjena je povećanje broja dražbenih koraka te njihov iznos, čime će se svakako postići postizanje povoljnije cijene u kraćem roku. Tako će prilikom davanja ponude korisnik moći odabrati između jednog, tri, pet ili deset dražbenih koraka, čija vrijednost je ovim izmjenama Pravilnika povećana." ${ }^{64}$

Dakle, hrvatsko se pravo s mogućom zloupotrebom nadmetanja suočava tako što ograničava pravo ponuđača da samostalno odredi iznos ponude koju može načiniti. Ono se ne ograničava samo na propisivanje minimuma ponude, tj. iznosa ispod kojeg ponuda ne može biti učinjena u odnosu na posljednju valjanu ponudu, nego propisuje i njezin maksimum, tj. iznos od kojeg ponuda ne može biti veća u odnosu na posljednju valjanu ponudu. Ipak se čini da mogućnost preskakanja više dražbenih koraka, pri njihovoj povećanoj vrijednosti, otvara mogućnost prethodno opisanoj prvoj zloupotrebi.

Sličnost s hrvatskim pravom postoji u pravu Crne Gore. Zakon o izvršenju i obezbjeđenju Crne Gore (dalje u tekstu: ZIO CG) ${ }^{65}$ propisuje da se, ako najmanje jedan sudionik prihvati objavljenu cijenu, objavljuje sljedeća cijena koja je viša od prethodne te da se ovaj postupak ponavlja sve dok posljednja objavljena cijena ostane neprihvaćena. Prilikom objavljivanja cijene sud, odnosno javni izvršitelj, dužan je brinuti se da svako sljedeće povećanje cijene ne bude nerazmjerno s posljednjom objavljenom cijenom. Javno nadmetanje se zaključuje neposredno poslije neprihvaćanja posljednje objavljene cijene. ${ }^{66}$ Dakle, crnogorsko pravo također poznaje dražbeni korak $\mathrm{u}$ određenoj formi jer stranke nisu slobodne samostalno dati ponudu u iznosu kojem žele, nego su u mogućnosti jedino pri-

63 Vidi članak 20. Pravilnika.

64 Vidi https://lider.media/ukratko/demanti-clanka-sustav-e-drazbi-prednost-daje-profesionalcima-s-jakim-racunalima-2/ (12. veljače 2019.).

65 Zakon o izvršenju i obezbjeđenju Crne Gore, Službeni list Crne Gore, br. 36/2011, 28/2014, 20/2015 i 22/2017.

66 Članak 178. ZIO-a CG. 
hvatiti ponudu po cijeni koja je objavljena. Ipak, za razliku od hrvatskog prava, smatramo da crnogorsko rješenje trpi nedostatke zbog toga što u ZIO-u CG nije propisan točan iznos dražbenog koraka, tj. točan iznos za koji će sljedeća objavljena ponuda biti viša od prethodne, što negativno utječe na predvidivost postupka.

Zanimljivo je i da je ranije izvršno pravo Srbije poznavalo dražbeni korak kod prodaje nekretnina u izvršnom postupku. Zakon o izvršenju i obezbeđenju Republike Srbije iz $2011 .{ }^{67}$ propisivao je da je cijena koja se objavljuje mogla biti viša najviše za $5 \%$ od prethodne cijene. ${ }^{68} 2015$. godine donesen je novi Zakon o izvršenju i obezbeđenju Republike Srbije (dalje u tekstu: ZIO RS) ${ }^{69}$ koji je do izmjena iz 2019. godine bio napustio sistem dražbenog koraka. Inicijativa u postupku javnog nadmetanja prenesena je u potpunosti na ponuđače te se slijedio sistem "tko ponudi više" bez ograničenja. ${ }^{70}$ Komentatori Zakona o izvršenju i obezbeđenju Srbije, u kojem je dražbeni korak bio ukinut, navode da je do promjene došlo uslijed namjere zakonodavca da ubrza postupak jer je objavljivanje cijene koja je mogla biti viša za najviše 5 \% od prethodne cijene usporavalo postupke javnog nadmetanja. ${ }^{71}$

Izmjene članka 179. ZIO-a RS iz 2019. ponovno su uvele dražbeni korak u izvršni postupak. Nove izmjene predviđaju da ako najmanje jedan sudionik prihvati početnu cijenu, javni izvršitelj objavljuje sljedeću cijenu koja je viša, i to najviše za $10 \%$ od početne cijene. Ovaj postupak ponavlja se sve dok posljednja objavljena cijena ostane neprihvaćena, nakon čega se javno nadmetanje zaključuje. Dakle, inicijativa za stavljanje više ponude prebačena je ponovno sa sudionika javnog nadmetanja na voditelja postupka.

U obrazloženju ove izmjene navedeno je da su postojeća pravila o tijeku javnog nadmetanja (bez dražbenog koraka, prim. aut.) dovela do velikih problema u praksi. Zbog toga se zakonodavac odlučio vratiti na rješenja iz 2011. godine jer je, kako stoji u obrazloženju zakona, takav sistem javnog nadmetanja pokazao mnogo bolje rezultate od onog sistema koji je uveden 2015. godine. Nadmetanje

67 Zakon o izvršenju i obezbeđenju Srbije, Službeni glasnik Republike Srbije, br. 31/2011, 99/2011, 109/2013, 55/2014 i 139/2014.

68 Nikolić, M.; Šarkić, N., Komentar Zakona o izvršenju i obezbeđenju, Paragraf Co, Novi Sad, 2016., str. 221.

69 Zakon o izvršenju i obezbeđenju Republike Srbije, Službeni glasnik Republike Srbije, br. 106/2015, 106/2016 - autentično tumačenje i 113/2017 - autentično tumačenje, 54/2019.

70 Nikolić, M.; Šarkić, N., Komentar Zakona o izvršenju i obezbeđenju: (sudska praksa, teorija), Službeni glasnik, Pravni fakultet Univerziteta Union, Beograd, 2018., str. 334. 
bez dražbenog koraka dovodilo je do toga da "u pojedinim slučajevima ... pravo nadmetanja među potencijalnim kupcima i ne postoji." 72

Očito je da je zakonodavac ponovno odvagnuo suprotstavljene interese i utvrdio da je manje problematično nešto duže trajanje postupka javnog nadmetanja od mogućnosti zloupotrebe prava koju je sud nemoćan ispraviti.

Novi ZIO RS od rješenja u BiH razlikuje se i po tome što kroz različitu regulaciju jamstva u izvršnom postupku dodatno ograničava mogućnost vršenja prve zloupotrebe (vidi III.6.).

Kako prava susjednih država poznaju dražbeni korak u određenoj formi, a i pravo Republike Srpske, trebalo bi razmisliti o njegovu uvođenju u pravni poredak u $\mathrm{FBiH}$ i BD BiH. Posebno zbog sličnosti pravnih tradicija susjednih država s BiH, dražbeni korak mogao bi biti poznato i provjereno rješenje koje je adekvatno za suočavanje sa zloupotrebom javnog nadmetanja davanjem nerealno visokih ponuda.

\section{ODUSTAJANJE PONUĐAČA OD KUPOVINE NEKRETNINE U POSTUPKU JAVNOG NADMETANJA (FIKTIVNA PONUDA) KAO VID ZLOUPOTREBE PRAVA}

\section{III.I. Uvod}

U ovom dijelu rada bit će analizirana situacija u kojoj sudionici u izvršnom postupku odustajanjem od (pretjerano visoke, fiktivne) ponude zloupotrebljavaju mehanizam javnog nadmetanja u $\mathrm{BiH}$ i onemogućavaju prodaju nekretnine u izvršnom postupku. Ova je zloupotreba posebno opasna u Federaciji BiH u vezi s odredbom članka 89. st. 5. ZIP-a FBiH koji predviđa mogućnost prodaje nekretnine na trećem ročištu bez ograničenja cijene. Moguće je odustajanjem od ponude ciljano voditi trećem ročištu i omogućiti npr. da jedna osoba ciljano kupi nekretninu za cijenu znatno niže od procijenjene. ${ }^{73}$ Zloupotreba o kojoj je riječ odnosi se na situaciju u kojoj tri nesavjesne osobe daju nerealno visoke ponude u licitaciji, pri čemu sud, budući da je ograničen na tri najbolja ponuđača, ne može uzeti u obzir ponude četvrtog ili bilo kojeg sljedećeg ponuđača te je prisiljen oglasiti prodaju neuspjelom i zakazati novo ročište.

72 Obrazloženje uz Nacrt Zakona o izmjenama i dopunama Zakona o izvršenju i obezbeđenju, str. 22, dostupno na: mpravde.gov.rs/files/Образложење\%20Нацрта\%20 закона\% $20 о \% 20$ изменама $\% 20$ и\% 20 допунама\% 203 акона\% 20 \% 20 извршењу\% 20 и\%20обез...\% (20. veljače 2021.).

73 Vidi u: Povlakić, op. cit. u bilj. 7. 
Smatramo da neadekvatno zakonsko rješenje, koje ne nudi efektivnu prevenciju, omogućava ovu zloupotrebu bez posebnog truda onih koji je namjeravaju izvršiti, dok savjesne sudionike u postupku ostavlja bez bilo kakve neposredne zaštite ako sudovi ne odluče aktivnije djelovati.

\section{III.2. Ograničenost suda na tri najbolja ponuđača kao okolnost koja dovodi do zloupotrebe prava}

Zakoni o izvršnom postupku u BiH propisuju da je nakon završetka licitacije ponuđač s najvećom ponudom dužan uplatiti prodajnu cijenu umanjenu za položenu jamčevinu. Rok uplate ne može biti duži od 30 dana, a određuje ga sud. U slučaju da najbolji ponuđač u ostavljenom roku ne izvrši uplatu, sud će zaključkom odrediti da se nekretnina ima prodati drugom najboljem ponuđaču, ostavljajući mu rok ne duži od 30 dana za deponiranje cijene. Ako ni drugi ponuđač ne deponira cijenu, sud će postupiti isto i u odnosu na trećeg najboljeg ponuđača. ${ }^{74}$

Zakoni o izvršnom postupku u BiH sadržavaju proturječnost kada je u pitanju postupanje suda u slučaju kada sva tri ponuđača ne uplate cijenu. Naime, oni propisuju da u slučaju da sva tri ponuđača s najvišom ponudom ne ispune svoje obaveze plaćanja prodajne cijene u određenim rokovima, sud može (isticanje autora) oglasiti da prvo ročište nije uspjelo i zakazati novo ročište. ${ }^{75} \mathrm{U}$ drugom dijelu zakona sadržane su donekle kontradiktorne odredbe ${ }^{76}$, točnije propisano je da će sud u roku od 30 dana zakazati ročište (isticanje autora) u slučaju da tri ponuđača s najvišom ponudom na prvom ročištu nisu uplatila prodajnu cijenu.

Dok jedna zakonska odredba propisuje jasnu obavezu suda da, u slučaju da nijedan od tri najbolja ponuđača ne deponira cijenu u ostavljenom roku, zakaže sljedeće ročište, druga zakonska odredba ostavlja ovu odluku sudu i time unosi određeni stupanj nesigurnosti jer nisu poznate alternative koje sud ima u odnosu na tu mogućnost. Ako sud ne bi bio obavezan donijeti odluku o zakazivanju sljedećeg ročišta, postupak se ne bi mogao razvijati u vremenu, niti bi mogao biti obustavljen jer uvjeti za obustavu postupka nisu ispunjeni ${ }^{77}$, što nas dovodi

74 Članak 92. ZIP-a FBiH, članak 92. ZIP-a RS, članak 113. ZIP-a BD BiH.

75 Članak 92. st. 3. ZIP-a FBiH, članak 92. st. 3. ZIP-a RS, članak 113. st. 3. ZIP-a BD $\mathrm{BiH}$.

76 Članak 89. st. 3. ZIP-a FBiH, članak 89. st. 3. ZIP-a RS, članak 110. st. 3. ZIP-a BD $\mathrm{BiH}$.

77 Članak 63. ZIP-a FBIH, članak 63. ZIP-a RS, članak 78. ZIP-a BD BiH. 
do zaključka da je upotreba riječi "može" vjerojatno omaška zakonodavca te da je sud u takvoj situaciji obavezan zakazati sljedeće ročište. ${ }^{78}$

Iz ovoga bi slijedilo da su samo ponude prva tri ponuđača relevantne, odnosno da se ponude četvrtog i svih daljih ponuđača uopće neće uzeti u obzir. U prilog tezi da je sud obavezan zakazati novo ročište govore i odredbe koje propisuju da će se ponuđačima čija ponuda nije prihvaćena, osim za tri najbolja ponuđača, vratiti jamčevinu odmah nakon zaključenja javnog nadmetanja. ${ }^{79}$ To znači da sud nije u mogućnosti uzeti u obzir ponude četvrtog i daljnjih ponuđača iz jednostavnog razloga što će oni dobiti natrag svoju položenu jamčevinu, pa sud u momentu njihova pozivanja na uplatu kupovne cijene (nakon što to odbiju tri najbolja ponuđača) nema ni minimum garancije koji ima u odnosu na prva tri ponuđača. O neadekvatnosti garancije koju položena jamčevina pruža bit će više riječi u odjeljku III.3.

Imajući u vidu odredbe koje reguliraju najnižu cijenu za koju nekretnina može biti kupljena na javnom nadmetanju ${ }^{80}$, postavlja se pitanje smisla ovakvog ograničenja. Naime, predmetne odredbe propisuju da se nekretnina na prvom ročištu za javno nadmetanje ne može prodati ispod polovine utvrđene vrijednosti, odnosno da na drugom ročištu nekretnina ne može biti prodana za manje od jedne trećine vrijednosti utvrđene zaključkom o prodaji. Svrha ovih odredbi je zaštita izvršenika, tj. vlasnika nekretnine, jer onemogućuju da se nekretnina koja je predmet izvršenja proda u bescjenje. Dok citirane odredbe štite izvršenika, nije jasno zbog čega je sud ograničen na prve tri najbolje ponude, u hipotetičkoj situaciji u kojoj postoje ponude koje zadovoljavaju odredbe o visini najniže cijene na prvom i drugom ročištu. Moguća je situacija u kojoj postoje ponude veće od zakonskog minimuma, ali sud njih nije u mogućnosti uzeti u obzir zbog odredaba koje ga ograničavaju na prva tri najbolja ponuđača. Smatramo da se time sud prilikom javnog nadmetanja bespotrebno ograničava, kao i potencijalni kupci, jer njihove ponude, iako visinom odgovarajuće, neće biti uzete u obzir. Utoliko se postavlja pitanje koji je smisao odredbe članka 90. st. 5. ZIP-a FBiH / ZIP-a RS te članka 11l. st. 5. ZIP-a BD BiH prema kojoj sud utvrđuje listu ponuđača koji su ponudili cijenu iznad minimalne. Ako se svi oni neće uzeti u obzir, onda je ta odredba potpuno nepotrebna.

78 Povlakić, u: Daupović et al., op. cit. u bilj. 59, str. 356.

79 Članak 86. st. 4. ZIP-a FBiH, članak 86. st. 4. ZIP-a RS, članak 107. st. 5. ZIP-a BD $\mathrm{BiH}$.

80 Članak 89. st. 2. i 4. ZIP-a FBiH, članak 89. st. 2. i 4. ZIP-a RS, članak 110. st. 2. i 4. ZIP-a BD BiH. 
Ako je zaštita izvršenika razlog uspostavljanja ovog ograničenja, onda se postavlja pitanje nepostojanja najniže cijene na trećoj licitaciji u FBiH. S jedne strane ZIP FBiH ograničava sudionike u javnoj prodaji nekretnine, iako je interes izvršenika već zaštićen kroz najmanju cijenu na prvoj i drugoj prodaji, dok, s druge strane, dozvoljava da se na trećoj prodaji nekretnina proda u bescjenje. Moguća je banalna situacija u kojoj nekretnina nije prodana za cijenu iznad polovine ili trećine vrijednosti, iako su postojale validne ponude bilo kojeg sljedećeg ponuđača, pa nekretnina bude prodana na trećoj prodaji u bescjenje. Ograničenje koje ZIP FBiH propisuje u pogledu tri najbolje ponude ima dodatnu dimenziju ugrožavanja interesa izvršenika u odnosu na ZIP RS i ZIP BD $\mathrm{BiH}$. Smisao takvog zakonskog rješenja je pogotovo upitan ako ga usporedimo s odredbama o javnoj prodaji pokretnih stvari u izvršnom postupku. Zakoni o izvršnom postupku u BiH propisuju da će ponuđač s najvećom ponudom platiti cijenu za pokretnu stvar odmah nakon objavljivanja rezultata ako sud zaključkom ne odluči drukčije. ${ }^{81}$ Ako ponuđač ne plati odmah po pozivu suda, drugi ponuđač će biti proglašen kupcem i platit će onu cijenu koju je on ponudio i tako redom. Ograničenje koje je propisano u odnosu na nekretnine ne postoji u odnosu na pokretne stvari.

Usprkos postojanju ovakvog manje-više jasnog zakonskog rješenja, njegova nelogičnost bila je predmetom odlučivanja sudova u BiH. Vrhovni sud Federacije $\mathrm{BiH}$ (dalje u tekstu: VS FBiH) u jednoj je svojoj odluci o spornom pravnom pitanju istaknuo sljedeće: "Prodaja nekretnine se smatra neuspjelom ako na zakazano ročište za javnu prodaju ne pristupi nijedan ponuđač, ako su na održanom ročištu date ponude koje se ne mogu uzeti u razmatranje, i ako ponuđač odustane od ponude, pa će, shodno tome, sud zakazati sljedeće ročište (drugo ili treće) za prodaju nekretnine." 82 Međutim, u ovoj odluci VS-a FBiH nije rečeno o kojem je ponuđaču riječ, samo o trećem ili o nekom slabije rangiranom ponuđaču. Ovaj sud nije bio izričito restriktivan. VS FBiH je time potencijalno ostavio otvorena vrata za nešto smjelije tumačenje spornih odredaba.

Upravo u tom smislu odlučivano je pred Kantonalnim sudom u Sarajevu u predmetu broj 650 Ip 30844018 Pž od 31. 10. 2018. godine. U žalbenom postupku problematizirano je pitanje prihvaćanja ponude četvrtog ponuđača, pri čemu je Kantonalni sud primijenio teleološko tumačenje i dao primat namirenju tražitelja izvršenja i okončanju izvršnog postupka nad restriktivnim tumačenjem sporne odredbe. Ovaj sud nije smatrao spornom činjenicu da ZIP FBiH

81 Članak 131. st. 2. ZIP-a FBiH, članak 131. st. 2. ZIP-a RS, članak 150. st. 2. ZIP- BD $\mathrm{BiH}$.

82 Odluka Vrhovnog suda Federacije BiH 280 I 052479 16 Spp od 5. 12. 2016. 
propisuje da se u obzir uzimaju samo ponude tri najbolja ponuđača, odnosno nije se pozivao na to da sud može (ali i ne mora) oglasiti da ročište nije uspjelo, već je naglasio cilj izvršnog postupka te činjenicu da se tražitelj izvršenja nije protivio uzimanju u obzir četvrte najbolje ponude, kao i očitu nesavjesnost prva tri ponuđača.

Kantonalni sud u Sarajevu isto je stajalište zauzeo u svojoj odluci 650 Ip 23139620 Pž 3 od 4. 2. 2020. godine. U ovom slučaju potvrdio je odluku Općinskog suda koji je nekretninu dosudio osmom po redu ponuđaču. Prva tri ponuđača nisu platila cijenu u predviđenom roku, nakon toga je sud pozvao četvrtog, petog, šestog i sedmog ponuđača da plate, što oni nisu učinili, ali je osmi ponuđač, koji je očito u danom slučaju bio jedini ozbiljni ponuđač, izjavio da nije odustao od namjere kupnje i njemu je nekretnina bila i dosuđena. Do kojih razmjera se otišlo u vezi s ovom vrstom zloupotrebe procesnih prava vidljivo je iz činjenice da se pojavilo sedam fiktivnih ponuđača. Prva tri ponuđača uložila su apelaciju Ustavnom sudu BiH. U svojem odgovoru Kantonalni sud u Sarajevu je istaknuo “... da iz citiranih odredbi slijedi da nije isključeno diskreciono pravo suda da pozove na uplatu i ostale ponuđače redom prema utvrđenoj listi, te da nije obvezan zakazati drugu prodaju, ukoliko ocijeni da bi se svrha ovršnoga postupka (namirenje povjeritelja) ostvarila prodajom nekretnine onome ponuđaču koji će biti spreman (ili je od početka bio spreman) platiti prodajnu cijenu." Ustavni sud $\mathrm{BiH}$ nije odlučio o meritumu, već je apelaciju proglasio ratione materiae inkompatibilnom Ustavu BiH jer su je uložila tri ponuđača koja su odustala od ponude i o čijim se pravima nije odlučivalo u predmetnom izvršnom postupku. ${ }^{83}$

Takva praksa Kantonalnog suda kao prioritet svojeg djelovanja postavlja jedan od osnovnih ciljeva izvršnog postupka - efikasno namirenje vjerovnika, ali nam se čini da je i uz dobro odmjereno rješenje ovakvo tumačenje prije contra legem negoli praeter legem. Takvo postupanje, koliko god logično i svrsishodno, ipak je suprotno slovu zakonskih odredaba i upitno je hoće li biti prihvaćeno kao univerzalno rješenje za sve izvršne sudove $\mathrm{u} \mathrm{BiH}$. U svakom slučaju to rješenje treba biti model za zakonsko rješenje de lege ferenda.

83 Odluka Ustavnog suda BiH AP-1872/20 od 23. 6. 2020. Ustavni sud bio je dosljedan u svojem stavu izraženom u nizu ranijih odluka (npr. AP-1261/07 od 10. 1. 2008.) da ako u predmetnom izvršnom postupku nije odlučivano o građanskim pravima apelanta, apelant ne može uživati zaštitu prava garantiranih Ustavom. Ovdje sud slijedi praksu ESLJP-a (v. slučaj Pronina protiv Rusije, odluka o dopustivosti od 30. 6. 2005. godine, aplikacija broj 65167/01, te Thomas protiv Ujedinjenog Kraljevstva, presuda od 10. 5. 2005. godine, aplikacija broj 19354/02) i vrlo je restriktivan kada je u pitanju prihvaćanje apelacije u izvršnom postupku zbog povrede prava na pravično suđenje. 


\section{III.3. Polaganje jamčevine kao okolnost koja dovodi do zloupotrebe prava}

Sudionici u javnom nadmetanju dužni su položiti jamčevinu prije njegova početka. Jamčevina iznosi jednu desetinu određene vrijednosti nekretnine s tim što u BiH ne može iznositi više od 10.000 KM. ${ }^{84}$ Ponuđačima čija ponuda nije prihvaćena, osim za tri najbolja ponuđača, vratit će se jamčevina odmah nakon zaključenja javnog nadmetanja. Ranije smo naveli koje su posljedice $u$ situaciji kada tri najbolja ponuđača ne uplate cijenu u rokovima. Postavlja se pitanje postoje li negativne posljedice koje bi vodile tome da ponuđači koji ne uplate cijenu u rokovima izgube položenu jamčevinu. Kakav karakter ima položena jamčevina?

Propisano je da se iz jamčevine prvog najboljeg ponuđača, koji u predviđenom roku ne uplati prodajnu cijenu, pokrivaju troškovi neuspjelog ročišta. Ako se ti troškovi ne mogu namiriti u cijelosti iz iznosa njegove jamčevine, razlika se namiruje iz jamčevine drugog najboljeg ponuđača ako i ovaj odustane od kupovine nekretnine. Ta pravila se shodno primjenjuju i u slučaju odustanka trećeg najboljeg ponuđača. Troškovi održavanja sljedećeg ročišta pokrivaju se razmjerno iz jamčevine ponuđača kojima je nekretnina prodana, a koji prodajnu cijenu nisu uplatili u određenom roku. Dok entitetski zakoni o izvršnom postupku propisuju da će se preostali iznos vratiti osobi koja je dala jamčevinu ${ }^{85}$, u BD BiH se eventualna razlika njima ne vraća, već ostaje imovina proračuna iz kojeg se financira rad suda. ${ }^{86}$

Iz priloženog slijedi da položena jamčevina u entitetima nema adekvatan punitivni karakter. ${ }^{87}$ Ponuđač koji u ostavljenom roku ne deponira iznos koji je ponudio na javnoj prodaji, umanjen za iznos položenog jamstva, pokriva samo troškove neuspjelog ročišta i troškove novog ročišta. Pri tome se troškovi neuspjelog ročišta namiruju u cijelosti iz položene jamčevine prvog kupca te se tek u slučaju nepotpunog namirenja prelazi na namirenje iz položene jamčevine drugog, a kasnije i trećeg kupca, koji su pri tome na isti način nesavjesno postupili kao i prvi ponuđač. Troškovi novog ročišta pokrivaju se razmjerno. Prvi kupac se nalazi u gorem položaju nego ostala dva jer je njegova položena jamčevina primarni izvor namirenja troškova neuspjelog ročišta, dok su položene jamčevine drugog i trećeg kupca tek uvjetno ugrožene. Ne vidi se razlog za takvo nejed-

84 Članak 86. ZIP-a FBIH, članak 86. ZIP-a RS, članak 107. ZIP-a BD BiH.

85 Članak 92. st. 6. ZIP-a FBiH, članak 92. st. 6. ZIP-a RS.

86 Članak 113. st. 6. ZIP-a BD BiH.

87 U tom smislu Povlakić, op. cit. u bilj. 7, str. 49 - 50. 
nako tretiranje osoba koje vrše istu zloupotrebu. Kako će ponuđači u pravilu sačuvati najveći dio položenog jamstva, budući da su troškovi javne prodaje u pravilu razmjerno mali u odnosu na cijenu nekretnine, neće im nastati značajni financijski gubitak u slučaju da kupovni iznos ne uplate u ostavljenom roku. U prilog tome govori i činjenica da ZIP FBiH ne propisuje pravila za snošenje troškova novog ročišta ako su sredstva jamčevine tri ponuđača iscrpljena. ${ }^{88}$

U najvećem broju slučajeva će dana jamčevina biti i više nego dostatna da pokrije troškove postupka. Izuzetno, u sporovima velike vrijednosti mogla bi nastati situacija da položeni iznos jamčevine ne bude dovoljan (maksimalni iznos jamčevine je $10.000 \mathrm{KM}) .{ }^{89}$ No, da bi do toga došlo, potrebno je da se kumulativno ispune tri uvjeta, a to je da je riječ o velikoj vrijednosti spora ${ }^{90}$, da u postupku sudjeluje advokat te da se postavi zahtjev za nadoknadom troškova advokata. Ako jedan od tri kumulativna uvjeta nije ispunjen, položena jamčevina u najvećoj će mjeri ostati očuvana, što nam govori o samo incidentalno punitivnom karakteru položene jamčevine. Pri tome ni velika vrijednost spora i sudjelovanje advokata ne moraju imati ovaj učinak. Prema članku 31. stavku 5. Zakona o advokaturi $\mathrm{FBiH}^{91}$, nakon izmjena usvojenih 2005. godine, nagrada advokatu za pruženu pravnu pomoć stranci u tijeku jedne rasprave ili jedne poduzete pravne radnje ne može prelaziti jednomjesečni prosječni osobni dohodak u Federaciji Bosne i Hercegovine. Viši dogovoreni iznos naknade ne može opteretiti drugu stranu, pa time ni utjecati na troškove postupka koji će pasti na teret druge strane, tako da u FBiH nije realno očekivati ni da će kod visoke vrijednosti spora biti iscrpljen iznos položene jamčevine. U Republici Srpskoj maksimalni je iznos advokatske nagrade u izvršnom postupku $2.700 \mathrm{KM}^{92}$ te je stoga i ovdje mogućnost iscrpljivanja položene jamčevine malo vjerojatna.

Ova mogućnost zloupotrebe postupka prodaje nekretnine u izvršnom postupku određena je kroz dvije okolnosti:

88 Zečević, E., Novi sudski izvršni postupak, Logos, Sarajevo, 2003., str. 72.

89 U Federaciji BiH u troškove održavanja ročišta pripadaju advokatski troškovi, i to: troškovi zastupanja, putni troškovi i dnevnice - članak 31. Advokatske tarife FBiH, Službene novine Federacije Bosne i Hercegovine, broj 22/2004 i 24/2004. Tarifa određuje da za obavljanje poslova izvan sjedišta advokatske kancelarije advokatu pripada naknada putnih troškova za prijevoz i dnevnica.

90 U skladu s člancima 12., 13. i 14. Tarife troškovi zastupanja se računaju na način da bi tek kod vrijednosti spora višoj od 100.000 KM advokatski troškovi premašili maksimalni iznos osiguranja od $10.000 \mathrm{KM}$.

91 Službene novine FBiH br. 40/2002, 29/2003, 18/2005 i 68/2005.

92 Članak 2. Tarife o nagradama i naknadi troškova za rad advokata, Službeni glasnik Republike Srpske, br. 68/2005. 
1. Činjenica da zakoni obavezuju sud da u obzir uzima samo tri najbolja ponuđača te da u slučaju da nitko od njih ne položi cijenu, zakon ne omogućava explicite sudu da pozove dalje najbolje ponuđače, već određuje da se zakazuje novo ročište. Pri tome zakazivanje novog ročišta nije opcija ako je već riječ o drugom, odnosno u Federaciji BiH trećem ročištu, već je moguće da sud donese i odluku o obustavi postupka. ${ }^{93}$ To sprječava namirenje vjerovnika u situaciji u kojoj postoji kupac (četvrti i daljnji ponuđači), tako da ono ima za posljedicu da se vršenjem ove zloupotrebe onemogući prodaja nekretnine i namirenje vjerovnika.

2. Jamčevina nema adekvatan punitivni karakter, već se iz nje mogu namiriti samo troškovi neuspjelog i troškovi novog ročišta, pri čemu se drugorangirani i trećerangirani ponuđač nalaze u povoljnijem položaju od prvog. Ostatak se u entitetima ima vratiti sudionicima u licitaciji usprkos njihovu neuplaćivanju cijene.

Rješenju prihvaćenom u BD BiH bez sumnje treba dati prednost. Trebalo bi se zalagati da sankcija za ovu zloupotrebu i u entitetima bude gubitak položene jamčevine.${ }^{94}$ Ovdje bi vrijedilo povući paralelu s odredbom članka 104. stavka 2. ZOO-a koja odražava načelo nemo auditur propriam turpitudinem allegans, odnosno princip da se nitko ne može pozvati na svoju nemoralnu radnju95 i koja ovlašćuje sud da ne dozvoli restituciju onoj stranci koja je protivno načelu savjesnosti i poštenja dovela do ništavosti pravnog posla. Smatramo da bi, dok se zakon ne izmijeni, sudovi u entitetima mogli analogno primjenjivati ovaj propis i odbijati vraćanje položene jamčevine strankama koje su zloupotrijebile svoja procesna prava davanjem fiktivne ponude.

\section{III.4. Posljedice fiktivne ponude za izvršni postupak}

Prethodno opisana zloupotreba, koja se ogleda u fiktivnom sudjelovanju u nadmetanju nakon čega prva tri ponuđača ne uplaćuju cijenu, može imati negativne posljedice za postupak izvršenja. Najbitnija posljedica te zloupotrebe jest nemogućnost namirenja tražitelja izvršenja, čak i kada on aktivno sudjeluje u postupku javnog nadmetanja, odnosno kada je i sam spreman licitirati i postati vlasnikom nekretnine u svrhu namirenja duga jer ostale osobe koje sudjeluju u

93 Članak 95. ZIP-a FBiH, članak 95. ZIP-a RS, članak 116. ZIP-a BD BiH.

$94 \mathrm{U}$ tom smislu Povlakić, op. cit. u bilj. 7, str. 50.

95 Više o tome Perović, S., u: Perović, S.; Stojanović, D., Komentar Zakona o obligacionim odnosima, knjiga prva, Kulturni centar Gornji Milanovac, Pravni fakultet Kragujevac, 1980., str. 361. 
postupku javnog nadmetanja imaju mogućnost nuđenja nerealno visokih iznosa jer nemaju stvarnu namjeru uplate cijene.

Druga posljedica tiče se tijeka postupka. Zakoni o izvršnom postupku BiH propisuju da će sud u ovoj situaciji zakazati novo ročište. Budući da se pravila održavanja drugog ročišta razlikuju samo u najnižoj cijeni za koju predmet izvršenja može biti prodan (minimalna cijena od trećine procijenjene vrijednosti umjesto polovine), ostaje logičan zaključak kako je moguće istovjetno postupanje sudionika u postupku javnog nadmetanja i na drugom ročištu. Dakle, u hipotetičkom slučaju iste osobe mogu postupiti identično i na drugom ročištu, osim ako im sud zbog prethodne zloupotrebe ne dozvoli sudjelovanje u javnoj dražbi. Izričito zakonsko ovlaštenje za takvo što ne postoji, a sud bi takvo sankcioniranje zloupotrebe prava morao detaljno obrazložiti. Autori ovog rada nisu optimistični u vezi s očekivanjem da sud postupi na takav način. U FBiH sud će zakazati i treće ročište, pri čemu opet postoji ista mogućnost zloupotrebe prava sudionika u javnom nadmetanju. U RS i BD BiH sud je u slučaju neuspjelog drugog ročišta dužan obustaviti postupak ${ }^{96}$, a u FBiH u slučaju da se nekretnina ne proda na trećem ročištu. ${ }^{97}$

Posljedice obustave izvršenja su u zakonima o izvršenju u BiH identične. Obustava izvršenja ne sprječava pokretanje novog izvršnog postupka radi naplate te tražbine na istoj nekretnini ${ }^{98}$, odnosno princip ne bis in idem u ovoj se konkretnoj situaciji ne primjenjuje..$^{99}$ To znači da se tražitelj izvršenja može dodatno usporiti u njegovu namirenju jer ako posljednja prodaja ne bude uspješna, on može predložiti novi predmet izvršenja ili ponovno započeti izvršni postupak na istom predmetu izvršenja, što, naravno, predstavlja financijski trošak, ali i vremenski gubitak. Pri tome tražitelj izvršenja ostaje bez garancije da se isto postupanje sudionika u postupku javnog nadmetanja neće ponoviti.

Prije donošenja rješenja o obustavi izvršenja sud će pozvati tražitelja izvršenja da predloži novo sredstvo ili predmet izvršenja, o čemu će sud odlučiti rješenjem u roku od 15 dana od dana prijama poziva. ${ }^{100}$ Rješenje o obustavi izvršenja sud će donijeti ako prijedlog ne bude u roku podnesen ili ako je prijedlog neosnovan. Logično je poći od pretpostavke da je tražitelj izvršenja prvotno predložio pred-

\footnotetext{
96 Članak 95. st. 1. ZIP-a RS, članak 116. st. 1. ZIP-a BD BIH.

97 Članak 95. st. 1. ZIP-a FBIH.

98 Članak 95. st. 3. ZIP-a FBIH, članak 95. st. 3. ZIP-a RS, članak 116. st. 3. ZIP-a BD $\mathrm{BiH}$.

99 Povlakić, u: Daupović et al., op. cit. u bilj. 59, str. 377.

100 Članak 63. st. 4. ZIP-a FBIH, članak 63. st. 4. ZIP-a RS, članak 78. st. 3. ZIP-a BD $\mathrm{BiH}$.
} 
met i sredstvo izvršenja koje će biti najefikasnije i najjednostavnije za uspješno okončanje izvršnog postupka ili je na to bio "prisiljen” jer imovina izvršenika obuhvaća samo jednu stvar koja je podobna za namirenje njegove tražbine. Stoga, zakoni o izvršnom postupku BiH omogućavaju nastavak postupka, ali ipak pružena mogućnost nije adekvatna alternativa za tražitelja izvršenja (može se dogoditi da nema drugog predmeta izvršenja, da drugi predmet izvršenja nije jednako adekvatan ili da je predmet jednako adekvatan kao i prvotni, ali tražitelj izvršenja na njemu nema sredstvo osiguranja, čime gubi pravo prvenstvenog namirenja, da na tom predmetu nema izvršni naslov i sl.). Zaključujemo kako mogućnost predlaganja novog premeta izvršenja ne može biti smatrana adekvatnim odgovorom na potencijalnu mogućnost zloupotrebe procesnih prava u postupku javne prodaje.

\section{III.5. Odluka Ustavnog suda BiH broj AP 1154/14101}

Ranije opisana situacija u kojoj se tri osobe pojavljuju kao fiktivni ponuđači u postupku javnog nadmetanja u svrhu usporavanja/obustave postupka i posljedičnog sprječavanja namirenja tražitelja izvršenja bila je predmetom odlučivanja Ustavnog suda BiH. Ustavni sud odlučivao je o apelaciji na odluku Okružnog suda u Bijeljini (dalje u tekstu: Okružni sud) i Osnovnog suda u Srebrenici (dalje u tekstu: Osnovni sud) u predmetu broj 820 I 00690014 Gž 2 Okružnog suda te predmetima broj 82 0 I 00690006 I 2 i broj 820 I 00690013 I 2 Osnovnog suda.

U postupku pred Osnovnim sudom apelanti su kao tražitelji izvršenja pokrenuli izvršni postupak radi isplate novčanog potraživanja prodajom nekretnina izvršenika. Osnovni sud zakazao je i održao tri ročišta za prodaju nekretnina koja su proglašena neuspjelima. ${ }^{102} \mathrm{Na}$ prijedlog punomoćnika tražitelja izvršenja sud je ponovno odredio ročište za prodaju nekretnina. Osnovni sud naveo je da je prvo ročište održano i proglašeno je neuspjelim. Na održanom drugom ročištu proglašeni su najbolji ponuđači koji nisu izvršili uplatu cijene u ostavljenom roku. Osnovni sud je zaključkom pozvao apelante (i ostale tražitelje izvršenja) da predlože novo sredstvo i predmet izvršenja te su oni ponovno predložili prodaju iste nekretnine. Osnovni sud navodi da je sud poslije prva tri neuspjela ročišta za prodaju nekretnina trebao tražiti tražitelje izvršenja

101 Službeni glasnik BiH, br. 12/2017, dostupno na: http://www.sluzbenilist.ba/page/akt/ CF16LMwLgztz5k76kjn45hoE=? fbclid=IwAR2VFQBSqz1QgrqEbRW83rg-JZdkze5-oCliddHbdblVJz8ylk7fDVBqhVk (12. studenoga 2019.).

$102 \mathrm{U}$ tom periodu treće je ročište postojalo i u pravu RS. 
da predlože promjenu predmeta ili sredstva izvršenja, što nije učinio, pa je sud opet odredio prodaju nekretnina, koja nije izvršena iako su se javili kupci. Osnovni sud držao je zahtjev za prodaju nekretnina koji su podnijeli tražitelji izvršenja neosnovanim te je, pozivajući se na članke 8. i 63. stavak 3. ZIP-a RS obustavio izvršenje. Okružni sud donio je Rješenje broj 820 I 00690014 Gž 2 kojim je žalbe tražitelja izvršenja odbio kao neosnovane i prvostupanjsko rješenje potvrdio. ${ }^{103}$

Apelanti su isticali kako su se osobe koje su se pojavile na licitaciji pojavili samo u svrhu sprječavanja prodaje ozbiljnom kupcu. U prilog svojoj tvrdnji istaknuli su činjenicu da jedna osoba koja je ponudila kupovnu cijenu nema novca ni za kolektivni smještaj u kojem borave. Upravo je te okolnosti Ustavni sud uzeo kao ključne u razmatranju navoda apelanata da su Osnovni i Okružni sud propustili spriječiti zloupotrebu prava, čime je apelantima povrijeđeno pravo na pravično suđenje. U točki 38. svoje odluke Ustavni sud navodi kako "načelo zabrane zloupotrebe (prava) obavezuje sud da ispita da li zaista stranka određenu radnju preduzima s nekim drugim ciljem i namjerom, a ne s ciljem donošenja odluke, odnosno okončanja postupka." Pri tome Ustavni sud ne nalazi da se sud treba baviti detaljima ili ulaziti u procjene hoće li do kupovine realno i doći, ali u svakom slučaju trebalo bi onemogućiti zloupotrebe prava od strane osoba za koje se pouzdano može smatrati da nikako ne bi bile u stanju zadovoljiti minimalne zahtjeve u svrhu realizacije preuzetih obaveza. ${ }^{104}$ Konačno, Ustavni sud u svojoj odluci navodi kako je činjenica da su Osnovni i Okružni sud u svojim rješenjima propustili obrazložiti prihvaćanje takvog postupanja te da takvo postupanje sudova predstavlja povredu prava na pravično suđenje.

Iz odluke Ustavnog suda jasno slijedi kako i Ustavni sud drži da su odredbe Zakona o izvršnom postupku, koje su predmet ovog rada, sporne te da otvaraju mogućnost zloupotrebe prava. Osporene odluke Okružnog i Osnovnog suda su ukinute te je Osnovnom sudu naloženo da donese novu odluku koja neće kršiti prava apelanata koja proizlaze iz prava na pravično suđenje. Međutim, postavlja se pitanje koje su posljedice ovakvog tumačenja tih odredaba od strane Ustavnog suda za izvršne sudove u BiH pro futuro. Mislimo da Ustavni sud u svojoj odluci nije uspostavio standard postupanja za druge izvršne sudove te da je ustanovio zloupotrebu prava i supsekventnu neobrazloženost presude kao aspekt kršenja prava na pravično suđenje samo u konkretnom slučaju na način koji ne može poslužiti kao opći obrazac postupanja.

103 Ustavni sud BiH, Odluka o dopustivosti i meritumu, AP 1154/14 od 11. 1. 2017., t. 10. -14 .

104 Ibid., t. 38. 
U konkretnom predmetu temeljni argument apelanata odnosio se na činjenicu da sudionici koji sudjeluju u postupku i koji su bili tri najbolja ponuđača nisu solventni te da jedan od njih ne može platiti ni kolektivni smještaj u kojem boravi. Ustavni sud je primijetio da je Osnovni sud propustio na adekvatan način ispitati te navode te drži kako bi trebalo onemogućiti zloupotrebe prava od strane osoba za koje se pouzdano može smatrati da nikako ne bi bile u stanju zadovoljiti minimalne zahtjeve preuzetih obaveza. Ovakvo rezoniranje Ustavnog suda ne može uspostaviti opći standard postupanja jer neće u svakom konkretnom slučaju biti moguće utvrditi posebne okolnosti na strani tri ponuđača. Na koji način bi izvršni sud uopće mogao utvrđivati minimalne zahtjeve u svrhu realizacije preuzetih obaveza i solventnost ponuđača u postupku javnog nadmetanja? U ovom slučaju je jedna osoba bila prima facie nesolventna, ali to ne znači da će sudovi u svakoj sljedećoj sličnoj situaciji imati tako očito nesolventnog ponuđača. Jedino moguće rješenje u ovom kontekstu bilo bi dostavljanje dokaza da osoba koja sudjeluje u postupku raspolaže sredstvima potrebnim za sudjelovanje u postupku javnog nadmetanja s obzirom na procijenjenu vrijednost nekretnine, o čemu propisi u BiH ne govore.

Čak i kada bi sudovi bili u mogućnosti utvrđivati solventnost i mogućnost ispunjenja obaveza s velikim stupnjem točnosti, time ni u kojem slučaju ne bi mogli u potpunosti spriječiti treće osobe da zloupotrebljavaju svoja prava na štetu tražitelja izvršenja. Sasvim je moguće da neka osoba ispunjava za sada nedefinirani standard solventnosti i dalje sudjeluje u postupku javnog nadmetanja bez stvarne namjere da postane vlasnikom nekretnine, odnosno s namjerom da spriječi tražitelja izvršenja u njegovu namirenju. U tom smislu ova odluka Ustavnog suda ni na koji način ne sprječava solventnog, ali nesavjesnog sudionika u postupku javnog nadmetanja da zloupotrijebi pravo. Ustavni sud kao ključni aspekt povrede prava na pravično suđenje istaknuo je činjenicu da odluke nižih sudova ne zadovoljavaju standard "obrazložene presude". Vjerujemo kako je sasvim moguće da se izvršni sud nađe u situaciji u kojoj treće osobe zloupotrijebe svoja prava u postupku na ranije opisan način, pri čemu sud ipak ima prostor da svoju odluku obrazloži (konkretno situacija u kojoj su sudionici solventni, ali nesavjesni).

U konkretnoj odluci Ustavni sud nije se bavio savjesnošću sudionika u postupku javnog nadmetanja, već se isključivo bavio kriterijem solventnosti, odnosno minimalnih zahtjeva u svrhu ispunjenja preuzetih obaveza sudionika u postupku. Pri tome, smatramo kako i pitanje ovog kriterija nije na adekvatan način uređeno, odnosno postupanje izvršnih sudova nije jasno definirano. Smatramo da zaštita savjesnih sudionika u postupku javnog nadmetanja treba biti predmetom zakonodavne intervencije koja bi uvela preventivne mjere (vidi III.7.), pri čemu je ostvarivanje u svakom konkretnom slučaju zadaća sudova. 


\section{III.6. Analiza rješenja u susjednim državama}

Nakon što smo elaborirali mogućnost zloupotrebe prava kroz davanje fiktivnih ponuda u postupku javnog nadmetanja, koju otvaraju zakonska rješenja u BiH, bit će izvršeno usporedba između rješenja u BiH i izabranih pravna poredaka u regiji, i to u pogledu dviju okolnosti koje su, po mišljenju autora ovog teksta, temelj za zloupotrebu prava u postupku javne prodaje nekretnine. To su ograničenost suda na tri najbolja ponuđača i nedostatak adekvatne sankcije u pogledu položenog jamstva.

U Republici Hrvatskoj se prema OZ-u i Pravilniku prodaja nekretnine obavlja elektroničkom javnom dražbom. Elektronička javna dražba počinje objavom poziva na sudjelovanje u elektroničkoj javnoj dražbi. ${ }^{105}$ U elektroničkoj javnoj dražbi kao kupci mogu sudjelovati samo osobe koje su prethodno dale jamčevinu. Ponuđačima čija ponuda nije prihvaćena FINA će vratiti jamčevinu na temelju naloga suda za prijenos novčanih sredstava. ${ }^{106}$ Sam iznos jamčevine nije određen ni u OZ-u ni u Pravilniku. Ipak, praksa je sudova da iznos jamčevine odrede u visini od $10 \%{ }^{107} \mathrm{Na}$ prvoj elektroničkoj javnoj dražbi nekretnina se ne može prodati ispod četiri petine utvrđene vrijednosti nekretnine, a na drugoj elektroničkoj javnoj dražbi nekretnina se ne može prodati ispod tri petine utvrđene vrijednosti nekretnine. ${ }^{108}$

$\mathrm{U}$ ovoj točki dolazimo do druge razlike između OZ-a i rješenja u $\mathrm{FBiH}$, odnosno ograničenosti suda na broj ponuđača u postupku javnog nadmetanja. Prema zakonima o izvršnom postupku u BiH sud je ograničen na tri najbolja ponuđača. U OZ-u takvo ograničenje ne postoji, čime je naša ranija argumentacija o nedostatku ratio ovakvog ograničenja u zakonima o izvršnom postupku u BiH dodatno ojačana. Prema OZ-u u rješenju o dosudi sud će odrediti da će se nekretnina dosuditi i kupcima koji su ponudili nižu cijenu, redom prema visini ponuđene cijene, ako kupci koji su ponudili veću cijenu nju ne polože u

105 Članak 97. st. 1. OZ-a.

106 Članak 99. OZ-a.

107 Zaključak o prodaji Općinskog suda u Splitu, Stalna služba u Imotskom, broj Ovr4763/17 od 25. 1. 2018. godine, preuzet s: http://www.otpnekretnine.hr/media/pdf/ Zaklju\%C4\%8Dak_za_1.dra\%C5\%BEbu.docx (31. prosinca 2018.); Zaključak Općinskog suda u Pazinu, broj Ovr-323/13-16 od 5. prosinca 2014. godine, preuzet s: http://sudovi.pravosudje.hr/OSPZ/img/File/10/Ovr-323-13\%20I\%20nekretnina. doc (31. prosinca 2018.); Zaključak o prodaji Općinskog suda u Opatiji, broj Ovr654/2013-33 od 21. listopada 2014. godine, preuzet s: http://www.opatija.hr/files/ file/novosti/2014/prosinac/Zakljucak--o-javnoj-drazbi.pdf (31. prosinca 2018.).

108 Članak 102. OZ-a. 
roku koji im je određen ili koji će im biti određen. U tom slučaju sud će donijeti posebno rješenje o dosudi svakom sljedećem kupcu koji je ispunio uvjete da mu se nekretnina dosudi, u kojem će odrediti rok za polaganje kupovnine. Sud će u tom rješenju najprije oglasiti nevažećom dosudu kupcu koji je ponudio višu cijenu. ${ }^{109} \mathrm{U}$ Hrvatskoj ne postoji ograničenje na prva tri ponuđača, što znači da se u obzir mogu uzeti sve ponude veće od zakonom utvrđenog minimuma. Interesi izvršenika su zaštićeni kroz najnižu cijenu ispod koje nekretnina ne može biti prodana, dok ograničenje na tri najbolja ponuđača ne postoji. Hrvatsko rješenje uklanjanjem ovog proizvoljnog ograničenja onemogućava ranije navedeni vid zloupotrebe prava u postupku prodaje nekretnina, što znači da bi i potencijalna zakonodavna intervencija u $\mathrm{BiH}$ trebala dovesti do brisanja odredaba koje se odnose na rečeno ograničenje.

Izmjene ZIO-a RS iz 2019. unijele su značajne novine u postupak javnog nadmetanja. Na javnom nadmetanju kao ponuđači mogu sudjelovati samo osobe koje su položile jamčevinu dva dana prije javnog nadmetanja. Jamčevina iznosi $15 \%$ procijenjene vrijednosti nekretnine. Kada zaključi javno nadmetanje, javni izvršitelj ispituje valjanost ponuda, objavljuje tko je najpovoljniji ponuđač. ${ }^{110} \mathrm{U}$ zaključku se navodi da će nekretnina biti dodijeljena ponuđaču koji je ponudio neposredno nižu cijenu od najpovoljnijeg ponuđača (drugi po redu ponuđač) ili ponuđaču koji je ponudio neposredno nižu cijenu od drugog po redu ponuđača (treći po redu ponuđač) ako najpovoljniji i drugi po redu ponuđač ne plate ponuđenu cijenu u roku koji je određen zaključkom o prodaji nekretnine. ${ }^{111}$

Drugom i trećem po redu ponuđaču vraća se jamčevina kad najpovoljniji ponuđač plati ponuđenu cijenu u roku, a trećem po redu ponuđaču i kad drugi po redu ponuđač plati ponuđenu cijenu u roku. Iz jamčevine ponuđača koji nije platio ponuđenu cijenu namiruju se troškovi javnog nadmetanja i razlika između cijene koju je on ponudio i plaćene cijene, a ako nakon toga preostane višak, uplaćuje se na račun proračuna Republike Srbije. Ako prva tri ponuđača ne plate ponuđenu cijenu u roku, iz njihove jamčevine namiruju se troškovi prvog i drugog javnog nadmetanja, i razlika u cijeni postignutoj na prvom i drugom javnom nadmetanju, odnosno razlika u cijeni koja je postignuta na drugom javnom nadmetanju i cijeni koja je postignuta u postupku prodaje putem neposredne pogodbe, a ako nakon toga preostane višak, uplaćuje se u proračun. ${ }^{112}$

\footnotetext{
109 Članak 103. st. 6. OZ-a.

110 Članak 180. ZIO-a RS.

111 Članak 181. ZIO-a RS.

112 Članak 182. ZIO-a RS.
} 
Dok je Zakon do 2019. propisivao da će se iz jamčevine namirivati isključivo troškovi javnog nadmetanja i razlika između cijene koju je on ponudio i plaćene cijene, zakonske izmjene situaciju mijenjaju u korist tražitelja izvršenja. Naime, iz jamčevine će se također namirivati troškovi neposredne pogodbe te razlika u cijeni koja je postignuta u postupku neposredne pogodbe. Najznačajnija promjena je ta da će se eventualni preostali višak uplaćivati u proračun.

Jamčevinu u svakom slučaju gubi sudionik koji ne ponudi ni početnu cijenu, kao i sudionik koji odustane od javnog nadmetanja. ${ }^{113}$ Javno nadmetanje nije uspjelo ni ako prva tri ponuđača s liste iz zaključka o dodjeljivanju nekretnine ne plate cijenu koju su ponudili u roku. ${ }^{114}$ Ako drugo javno nadmetanje nije uspjelo, javni izvršitelj odmah poziva tražitelja izvršenja da u roku od 15 dana izabere namirenje prodajom nekretnine neposrednom pogodbom ili prijenosom prava vlasništva na nekretnini. ${ }^{115}$ Iz relevantnih odredaba ZIO-a jasno je da i u Republici Srbiji postoji ograničenje na tri najbolja ponuđača, dok se ponude ostalih ponuđača ne uzimaju u obzir, pri čemu visina tih ponuda u odnosu na zakonski minimum nije relevantna. Iako i ZIO RS sadržava ograničenje na isključivo tri najbolja ponuđača, izmjena iz 2019. godine utvrđuje da je jamčevina nesavjesnog ponuđača (ako je riječ o jednom od trojice najboljih) za njega izgubljena protekom roka za uplatu cijene. Ovom izmjenom u potpunosti je ostvaren punitivni potencijal jamčevine. ${ }^{116}$ To znači da srbijansko rješenje redefinira karakter jamčevine na način da nesavjesni prvi ponuđač u potpunosti gubi cijeli iznos jamčevine ako ne uplati prodajnu cijenu. Na taj način bi u potpunosti bilo riješeno pitanje punitivnog karaktera jamčevine. Na ovaj put upozoreno je pod III.3., gdje se zagovaralo takvo rješenje u entitetima s pozivom na članak 104. stavak 2. i 3. ZOO-a.

Druga razlika između zakonskih odredaba u dvije zemlje tiče se mogućnosti koje stoje na raspolaganju tražitelju izvršenja. Primijetili smo kako zakoni o izvršnom postupku u BiH tražitelju izvršenja ne ostavljaju opcije koje zaista mogu dovesti do njegova namirenja. On može ponovno pokrenuti izvršni postupak na istoj nekretnini ili promijeniti predmet i sredstvo izvršenja, što je

\footnotetext{
113 Članak 182. ZIO-a RS.

114 Članak 183. ZIO-a RS.

115 Članak 184. ZIO-a RS.

116 Čak su i ranija rješenja ZIO-a RS sadržavala kvazipunitivne elemente jer se iz jamčevine namirivala razlika između cijene ponuđača čija je jamčevina i zaista ostvarene cijene, čime je ponuđač bio obeshrabren davati nerealno visoke ponude. Ipak, uvođenje odredbe kojom se preostali dio jamčevine uplaćuje u državni proračun pokazuje kako je zakonodavac u Republici Srbiji prepoznao nužnost adekvatnije regulacije tog dijela izvršnog postupka.
} 
ranije ocijenjeno kao neadekvatna alternativa koja ne štiti u potpunosti interese tražitelja izvršenja. S druge strane, ZIO RS ostavlja tražitelju izvršenja nešto širu mogućnost namirenja, kroz institute prodaje nekretnine neposrednom pogodbom i prijenosa prava vlasništva na nekretnini. To znači da nesavjesni ponuđači imaju manju mogućnost manipuliranja postupkom nego je to slučaj u izvršnom pravu u $\mathrm{BiH}$ jer je zloupotreba njihovih prava vezana isključivo uz postupak javnog nadmetanja i ne može se odigrati ako se tražitelj izvršenja namiruje neposrednom pogodbom ili stjecanjem vlasništva na predmetu izvršenja.

Zaključujemo kako je srbijanski izvršni postupak u odnosu na oba preduvjeta zloupotrebe prava povoljniji za tražitelja izvršenja, odnosno predstavlja efikasniju preventivnu zaštitu od zloupotrebe prava, nego što je to slučaj s rješenjima u $\mathrm{BiH}$.

ZIO Crne Gore ${ }^{117}$ uređuje pitanje redoslijeda ponuđača na identičan način kao i BiH i Srbija - tri ponuđača imaju povlašten položaj u odnosu na ostale. U slučaju neuspjeha prodaje nekretnine na tri nadmetanja koja crnogorski zakon propisuje javni izvršitelj će pozvati izvršnog vjerovnika da se odmah, a najkasnije u roku od pet dana, izjasni predlaže li prodaju neposrednom pogodbom. Ako se prodaji neposrednom pogodbom pristupi nakon tri neuspjela javna nadmetanja, prodajna cijena postaje predmet dogovora između strana $\mathrm{u}$ ugovoru o prodaji i za nju se ne traži suglasnost izvršnog dužnika. ${ }^{118}$ To znači da crnogorsko rješenje, slično kao i srbijansko, nudi “izlaz” tražitelju izvršenja u slučaju neuspjelih javnih prodaja. Crnogorsko rješenje, kao i srbijansko rješenje prije 2019. godine, propisuje kako će se iz položene jamčevine namiriti troškovi nove prodaje i nadoknaditi eventualna razlika između cijene postignute na ranijoj i novoj prodaji. ${ }^{119} \mathrm{U}$ tom smislu, mjere koje se primjenjuju u Crnoj Gori imaju djelomično punitivni karakter jer je nesavjestan ponuđač oprezniji u pogledu davanja nerealno visokih ponuda jer time direktno utiče na visinu razlike, odnosno visinu iznosa koji se ima platiti iz njegove jamčevine, što može efikasno spriječiti fiktivne ponude i zloupotrebu prava.

Ipak, iako se ovakvom rješenju može dati prednost u odnosu na rješenja u $\mathrm{BiH}$ jer može ograničiti fiktivne ponude, ono može voditi oštećenju interesa izvršenika s obzirom na to da neposredna pogodba nije vezana uz određenu minimalnu cijenu ispod koje se nekretnina ne može prodati.

117 Članak 180. ZIO-a CG.

118 Članak 95. ZIO-a CG.

119 Članak 180. ZIO-a CG. 


\section{III.7. Razmatranje rješenja de lege ferenda}

Kod formuliranja prijedloga za izmjenu zakona najprije ćemo se pozabaviti pitanjem ograničenja prema kojem se u obzir uzimaju isključivo tri najbolje ponude. Prethodno smo kritički sagledali ovo rješenje iz više aspekata te smatramo kako je ovakvo rješenje proizvoljno i ne štiti interese nijedne od stranaka uključenih u postupak. U tom smislu posebno je zanimljivo rješenje Republike Hrvatske - ono, naime, ne propisuje ovakvo ograničenje, već sud u obzir uzima redom sve ponude, dok god su one iste ili veće od zakonskog minimuma. Smatramo da bi ovakva zakonodavna intervencija u BiH efektivno spriječila opisanu mogućnost zloupotrebe prava putem davanja fiktivnih ponuda. Ugrožavanje interesa tražitelja izvršenja bilo bi izbjegnuto ako bi sud mogao uzeti u obzir i daljnje ponude.

Iako bi izostavljanje ograničenja na tri najbolja ponuđača riješilo nastalu situaciju, vjerujemo da je nužno razmotriti i sankcioniranje davanja fiktivnih ponuda. Naime, jamčevina koju stranke uplaćuju u svrhu sudjelovanja u javnom nadmetanju bez obzira na ishod ročišta ima se vratiti strankama, pa makar to bila tri ponuđača čijim mala fide postupanjem dolazi do sprječavanja tražitelja izvršenja u naplati tražbina kroz ranije elaboriranu opstrukciju. U tom smislu sasvim je logičan zaključak da je nužno sankcionirati nesavjesno postupanje time što jamčevina neće biti vraćena fiktivnim ponuđačima. Takvo rješenje postoji u Republici Srbiji i BD BiH. Uz činjenicu da fiktivni ponuđači ne bivaju sankcionirani gubitkom jamčevine, u FBiH i RS vrata zloupotrebe mogu biti još šire otvorena činjenicom da je njezin iznos nizak. Dok se taj iznos u Srbiji i Hrvatskoj određuje postotkom vrijednosti nekretnine, u BiH je to samo dijelom tako, a najveći iznos jest $10.000 \mathrm{KM}$, neovisno o vrijednosti nekretnine. Ako će fiktivno sudjelovanje $\mathrm{u}$ nadmetanju voditi tome da nekretninu velike vrijednosti zadrži izvršenik, odnosno da uopće ne dođe do prodaje ili da se lakše dođe do drugog (ili čak trećeg ročišta u FBiH) i da nekretninu po niskoj cijeni kupi određena osoba, jasno je da je ovu igru lakše igrati s manjim ulogom. Zakonska rješenja koja imaju ograničenja u pogledu iznosa jamčevine, pri čemu se ni taj manji iznos ne mora nepovratno izgubiti u cijelosti, ne mogu zaslužiti pozitivnu ocjenu.

Također vrijedi istaknuti značajnu razliku između rješenja u Srbiji i Crnoj Gori i BiH u pogledu neuspješne prodaje na svim predviđenim ročištima za prodaju. U Crnoj Gori i Srbiji nakon neuspjeha javne prodaje na dva ročišta tražitelj izvršenja optira između prodaje putem neposredne pogodbe i prijenosa prava vlasništva na nekretnini, dok BiH tražitelj izvršenja nakon drugog, odnosno trećeg ročišta u FBiH, može samo odrediti drugi predmet izvršenja. Jasno je da je dodatni moment osiguranja od zloupotrebe i činjenica da usprkos malicioznom 
postupanju ponuđača tražitelj izvršenja može postati vlasnikom nekretnine koja je predmetom izvršenja te ovakva procesna opcija ima i funkciju "ventila" kako bi se izbjegla situacija u kojoj se tražitelj izvršenja u BiH lako može naći. Iz ovoga proizlazi zaključak kako bi potencijalna zakonodavna intervencija mogla ići i u smjeru drukčijeg reguliranja procesnih posljedica neuspjelih ročišta za prodaju nekretnine, što bi trebalo imati karakter preventivnih mjera za suzbijanje ove zloupotrebe.

\section{ZAKLJUČAK}

U radu se nastojalo pokazati kako je lako organizirati i izvršiti zloupotrebu odredaba zakona koji reguliraju izvršno pravo u BiH o najpovoljnijoj ponudi, odustanku od ponude i polaganju jamčevine radi sudjelovanja u javnom nadmetanju. Elaborirana je mogućnost zloupotrebe mehanizma javne dražbe, i to davanjem nerealno visokih ponuda koje onemogućavaju nadmetanje, a zatim odustajanjem takvih ponuđača od uplate cijene, a sve u svrhu sprječavanja namirenja tražitelja izvršenja. Izloženi mehanizmi zloupotrebe posljedica su neadekvatnih zakonskih rješenja u zakonima o izvršnom postupku u BiH. Pozitivno pravo je, posebno u entitetima, ovdje vakantno i pogoduje tim zloupotrebama.

Budući da je izostala adekvatna zakonska regulativa, nužno bi bilo u svakom konkretnom slučaju ispitivati motive djelovanja sudionika u javnom nadmetanju, što u pravilu nije u mogućnosti činiti ni sud ni drugi sudionici, ili je pak moguće uz osobite napore za koje ne postoje adekvatni vremenski i materijalni resursi. Sve navedeno, u kombinaciji, omogućava svima koji u izvršnom postupku po niskoj cijeni žele postati vlasnici nekretnina ili onima koji žele spriječiti prodaju da to inženjeringom ročišta za javno nadmetanje i odustankom od uplate cijene bez velikih napora i troškova učine. Na taj način može se polučiti rezultat za koji sa sigurnošću možemo reći da nije u skladu s onim što su zakonodavci imali u vidu kada su usvajali nove zakone o izvršnom postupku u BiH. Različiti su razlozi koji mogu ugroziti efikasnost izvršnog postupka. Ovdje analizirane zloupotrebe izvjesno su među tim razlozima. Osim toga, one ne ugrožavaju samo efikasnost postupka, već ometaju ostvarenje socijalne funkcije izvršnog postupka.

Smatramo da bi u situacijama kad je zakonodavac u prilici djelovati ex ante, određujući preventivne mjere koje sprječavaju predmetne zloupotrebe, tako trebao i postupiti. Naravno, prilično je realno očekivati da zakonodavac ne može zamisliti sve moguće oblike zloupotreba koje se mogu javiti prilikom primjene propisa, pa je dostupnost pravnih instituta koji omogućavaju ex post facto uklanjanje zloupotreba u izvršnom postupku potrebna - ali kao suplement, a ne supstitut adekvatnom ex ante pravnom mehanizmu. 
U tom smislu izloženi su prijedlozi de lege ferenda koji bi po uzoru na rješenja u komparativnom pravu mogli predstavljati zakonodavni odgovor na navedene zloupotrebe. Dražbeni korak je način sprječavanja zloupotrebe javnog nadmetanja, prisutan u različitim modalitetima u zemljama okruženja. Elektronička javna dražba i mogućnost preskakanja nekih dražbenih koraka može riješiti taj problem.

U pogledu mogućnosti nekažnjenog odustanka od nerealno visokih ponuda ili generalno odustanka da se uplati cijena, izložena su rješenja koja idu za tim da jasno definiraju punitivni karakter položene jamčevine. Osim toga ukazano je na to da je ograničenje na tri najbolja ponuđača (koja zatim odustaju od ponude) kontraproduktivno, pogotovo kod rješenja o minimalnoj cijeni ispod koje nekretnina ne može biti prodana na određenom ročištu; pokazali smo da bi i izvršenik i tražitelj izvršenja bili adekvatno zaštićeni ako bi sud mogao prihvatiti i daljnje ponude koje zadovoljavaju propozicije određenog ročišta. Za eventualne zakonodavne intervencije posebno je interesantno hrvatsko rješenje koje u potpunosti eliminira povlaštenu poziciju tri najbolja ponuđača, kao i rješenje u Srbiji i Brčko distriktu BiH, koje predviđa oduzimanje položene jamčevine u korist fiscusa u slučaju odustanka od kupovine.

Sve izloženo upućuje na to da evidentni potencijal postojećih zakonskih rješenja za zloupotrebu procesnih prava zaslužuje zakonodavnu intervenciju. Iako zakonska rješenja obavezuju sud da onemogući svaku zloupotrebu prava $\mathrm{u}$ postupku, to ne može biti jedini alat $\mathrm{u}$ borbi protiv zloupotrebe procesnih ovlaštenja. Analiza zakonskih rješenja u BiH pokazala je da određena rješenja pogoduju vršenju zloupotrebe prava i da ih treba izmijeniti te da bi to trebao biti prvi korak. Ovdje se ne želi negirati efikasnost instituta zabrane zloupotrebe prava, ali se zastupa stajalište da je institut reguliran bez jasnog obrisa, što može dati široku slobodu sudu, koju sudovi iz navedenih razloga mahom ne koriste. Intervencija zakonodavca u cilju jačanja preventivnih mehanizama kojima se sprječava vršenje zloupotrebe prava stoga ima posebnu važnost. Doktrina procesnog prava identificirala je niz zakonskih rješenja koja reformirano izvršno pravo u BiH odnosno u regiji nudi kao preventivne mjere za sprječavanje već ranije identificiranih slučajeva zloupotrebe (npr. odredbe o relativnoj nesuspenzivnosti pravnih lijekova ${ }^{120}$, prigovoru trećeg, odredbe o dostavljanju, odredbe kojima se skraćuju prekluzivni rokovi, odlučivanje suda zaključkom na koji se

120 Više o tome kod Dika, M., Osnovne značajke i opći pregled prve novele hrvatskog ovršnog prava, u: Dika, M. (ur.), Reforma ovršnog i stečajnog prava, Organizator, Zagreb, 1999., str. 143. 
ne može uložiti pravni lijek itd.). ${ }^{121}$ Autori ovog rada zalažu se za izmjenu odredaba o javnom nadmetanju kako bi se u sustav izvršenja ugradili preventivni mehanizmi za sprječavanje zloupotrebe prava, što može biti efikasnije sredstvo od ex post intervencije sudova.

\section{BIBLIOGRAFIJA}

\section{Knjige i članci}

Ademović, N.; Marko, J.; Marković, G., Ustavno pravo Bosne i Hercegovine, Fondacija Konrad Adenauer e. V. Predstavništvo u Bosni i Hercegovini, Sarajevo, 2012.

Čalija, B.; Omanović, S., Građansko procesno pravo, Pravni fakultet Univerziteta u Sarajevu, Sarajevo, 2000.

Čalija, B., Zloupotreba prava u građanskom postupku, Godišnjak Pravnog fakulteta u Sarajevu, god. 12., 1964., str. 231 - 258.

Daupović, A.; Obradović, R.; Povlakić, M.; Zaćiragić, F.; Živanović, M., Komentari Zakona o izvršnom postupku u Federaciji Bosne i Hercegovine i Republici Srpskoj, Vijeće Evrope i Evropska komisija, Sarajevo, 2005.

de Morree, P., Rights and Wrongs under the ECHR: The prohibition of abuse of rights in Article 17 of the European Convention on Human Rights, Intersentia, Cambridge, 2016.

Dika, M., Osnovne značajke i opći pregled prve novele hrvatskog ovršnog prava, u: Dika, M. (ur.), Reforma ovršnog i stečajnog prava, Organizator, Zagreb, 1999. , str. 141 - 157.

Huseinbegović, A., Načela civilnog izvršnog postupka (doktorska disertacija), Pravni fakultet, Univerzitet “Džemal Bijedić”, Mostar, 2010.

Janevski, A.; Zoroska Kamilovska, T., Gragansko procesno pravo, knjiga prva, Parnično pravo, vtoro izmeneto i dopolneto izdanie, Pravni fakultet "Justinijan Prvi“ vo Skopje, Skopje, 2012.

Kamiloska-Zoroska, T., Reforme sistema izvršenja u državama regiona - Novi koncepti, kontroverze i dileme, u: Zbornik radova Međunarodnog naučnog skupa Harmonizacija građanskog prava u regionu, Pravni fakultet Univerziteta Istočno Sarajevo, Sarajevo, 2013., str. $447-477$.

Keča, R., Građansko procesno pravo, Priručnici za polaganje pravosudnog ispita, knjiga 7, Pravni fakultet Univerziteta u Beogradu, Javno preduzeće Službeni glasnik, Beograd, 2012.

121 Stanković, op. cit. u bilj. 36, str. 12 - 15; Omanović; Ruhotina, op. cit. u bilj. 34, str. $494-504$. 
Keča, R., Građansko procesno pravo, 2. izmijenjeno i dopunjeno izdanje, Pravni fakultet Univerziteta u Beogradu i Službeni glasnik, Beograd, 2010.

Kern, Ch.; Diehm, D. (ur.), ZPO Zivilprozesordnung, Kommentar, 2. neu bearbeitete und wesentlich erweiterte Ausgabe, Erich Schmidt Verlag, Berlin, 2020.

Kovačević Kuštrimović, R.; Lazić, M., Uvod u građansko pravo, Punta, Niš, 2008.

Krneta, S., Povreda „načela poštenja i savjesnosti“ kao razlog prestanka subjektivnih građanskih prava, Godišnjak Pravnog fakulteta u Sarajevu, god. 16. - 17., 1968. - 1969., str. 107 - 128.

Krneta, S., Subjektivna građanska prava, Enciklopedija imovinskog prava i prava udruženog rada, Službeni list SFRJ, Beograd, 1978.

Kulenović, Z.; Mikulić, S.; Milišić-Veličkovski, S.; Stanišić, J.; Vučina, D., Komentari Zakona o parničnom postupku u Federaciji Bosne i Hercegovine i Republici Srpskoj, Vijeće Evrope i Evropska komisija, Sarajevo, 2005.

Marković, M., Zloupotreba prava, Enciklopedija imovinskog prava i prava udruženog rada, Službeni list SFRJ, Beograd, 1978.

Mulabdić, S., Građansko procesno pravo, Pravni fakultet Univerziteta u Tuzli, Tuzla, 2010.

Nikolić, D., Uvod u sistem građanskog prava, 11. izmenjeno i dopunjeno izdanje, Univerzitet u Novom Sadu, Novi Sad, 2011.

Nikolić, M.; Šarkić, N., Komentar Zakona o izvršenju i obezbeđenju, Paragraf Co, Novi Sad, 2016.

Nikolić, M.; Šarkić, N., Komentar Zakona o izvršenju i obezbeđenju: (sudska praksa, teorija), Službeni glasnik, Pravni fakultet Univerziteta Union, Beograd, 2018.

Omanović, S., Glossarium uz novi Zakon o izvršnom postupku Federacije Bosne i Hercegovine, Univerzitet u Sarajevu, Sarajevo, 2005.

Omanović, S.; Ruhotina, A., Mjere za suzbijanje zloupotrebe procesnih ovlaštenja u izvršnom postupku, Godišnjak Pravnog fakulteta u Sarajevu, god. LXIII, 2020., str. 487 - 516.

Perović, S.; Stojanović, D. (red.), Komentar Zakona o obligacionim odnosima, knjiga prva, Kulturni centar - Gornji Milanovac, Pravni fakultet - Kragujevac, 1980.

Povlakić, M., Die praktischen Probleme des Vollstreckungsrechts - Dargestellt am Beispiel von Bosnien und Herzegowina u: Bundesministerium der Justiz und Deutsche Stiftung für internationale rechtliche Zusammenarbeit e.v. - IRZ (Hrsg.), Konferenzband „Rechtsstaat und Bürger - Anforderungen an eine moderne Justiz“, Dubrovnik, 4.12. - 8.12.2002., str. 77 - 86.

Povlakić, M., Osvrt na dva nova zakonska teksta u Federaciji BiH: Zakon o izmjenama i dopunama Zakona o izvršnom postupku, Zakon o finansijskom poslovanju, Nova pravna revija, br. 2, 2016., str. $24-35$. 
Povlakić, M., Prodaja nekretnine na trećem ročištu - da li je rješenje ovog problema na vidiku, Sudska praksa, br. 73, 2017., str. 39 - 60.

Poznić, B.; Rakić-Vodinelić, V., Građansko procesno pravo, Savremena administracija, Beograd, 1999.

Račić, R., Izvršno procesno pravo, Pravni fakultet Univerziteta u Banja Luci, Banja Luka, 2009.

Rakočević, M., Bona fides u parničnom postupku, Zbornik radova Pravnog fakulteta u Splitu, god. 55, br. 4, 2018., str 771 - 789.

Rechberger, W.; Oberhammer, P., Executionsrecht, 3. Auflage, WUV Universitätsverlag, Wien, 2002.

Schilken, E., Zivilprozessrecht, 6. Auflage, Vahlen, München, 2010.

Stanković, G., Građansko procesno pravo, IP Justinijan, Beograd, 2004.

Stanković, G., Zloupotreba prava stranaka u izvršnom postupku, Pravni život, br. 12, 2014., str. 5 - 18.

Stanković, G.; Račić, R., Parnično procesno pravo, Pravni fakultet Univerziteta u Banja Luci, Banja Luka, 2010.

Stojanović, D., Savjesnost $i$ poštenje, Enciklopedija imovinskog prava i prava udruženog rada, Službeni list SFRJ, Beograd, 1978.

Triva, S.; Dika, M., Građansko parnično procesno pravo, Narodne novine, Zagreb, 2004.

Triva, S.; Belajec, V.; Dika, M., Sudsko izvršno pravo, Informator, Zagreb, 1980.

Uitdehaag, J.; Vincken, E., Civil Enforcement in the Western Balkans, Balkans Enforcement Reform Project, Tirana, 2011.

Vedriš, M.; Klarić, P., Gradansko pravo, četvrto izdanje, Narodne novine, Zagreb, 2000.

Vodinelić, V., Građansko pravo, Uvod u građansko pravo i Opšti deo građanskog prava, drugo, izmenjeno i dopunjeno izdanje, Pravni fakultet Univerzitet Union, Beograd, 2014.

Zečević E., Novi sudski izvršni postupak, Logos, Sarajevo, 2003.

Zöller, R., ZPO Zivilprozesordnung, 29. Auflage, Verlag Dr. Otto Schmidt, Köln, 2012.

Zuglia, S., Građanski parnični postupak FNRJ, Školska knjiga, Zagreb, 1957.

\section{Propisi}

Advokatska tarifa FBiH, Službene novine Federacije Bosne i Hercegovine, br. $22 / 2004$ i $24 / 2004$ 
Ovršni zakon Republike Hrvatske, Narodne novine, br. 112/2012, 25/2013, 93/2014, 55/2016 i 73/2017

Pravilnik o načinu i postupku provedbe prodaje nekretnina i pokretnina u ovršnom postupku, Narodne novine, br. 93/2014 i 1/2019

Tarife o nagradama i naknadi troškova za rad advokata, Službeni glasnik Republike Srpske, br. 68/2005

Zakon o izvršnom postupku BD BiH, Službeni glasnik Brčko distrikta BiH, br. 39/2013 i 47/2017

Zakon o izvršenju i obezbeđenju Srbije, Službeni glasnik Republike Srbije, br. 31/2011, 99/2011, 109/2013, 55/2014 i 139/2014

Zakon o izvršenju i obezbjeđenju Crne Gore, Službeni list Crne Gore, br. 36/2011, 28/2014, 20/2015 i 22/2017

Zakon o izvršnom postupku Federacije BiH, Službene novine Federacije Bosne i Hercegovine, br. 32/2003, 52/2003, 33/2006, 3920/2006, 39/2009, 35/2012 i $46 / 2016$

Zakon o izvršnom postupku Republike Srpske, Službeni glasnik Republike Srpske, br. 59/2003, 85/2003, 64/2005, 118/2007, 29/2010, 57/2012, 67/2013, $98 / 2014$ i $66 / 2018$

Zakon o obligacionim odnosima FBiH, Službeni list SFRJ, br. 29/1978, 39/1985, 45/1989 i 57/1989, Službeni list RBiH 2/1992, 13/1993, 13/1994; Službene novine Federacije Bosne i Hercegovine, br. 29/2003 i 42/2011

Zakon o obligacionim odnosima RS, Službeni list SFRJ, br. 29/1978, 39/1985, 45/1989 i 57/1989, Službeni glasnik RS, br. 17/1993, 3/1996, 37/2001, 39/2003 i $74 / 2004$

Zakon o parničnom postupku BD BiH, Službeni glasnik Brčko distrikta BiH, br. $28 / 2018$

Zakon o parničnom postupku FBiH, Službene novine Federacije BiH, br. 53/2003, 73/2005, 19/2006 i 98/2015

Zakon o parničnom postupku RS, Službeni glasnik Republike Srpske, br. 58/2003, 85/2003, 74/2005, 63/2007, 105/2008 - odluka US, 45/2009 odluka US, 49/2009 i 6l/2013

Zakon o stvarnim pravima FBiH, Službene novine Federacije BiH, br. 66/2013 i $100 / 2013$

Zakon o stvarnim pravima RS, Službeni glasnik Republike Srpske, br. 124/2008, 3/2009, 58/2009, 95/2011, 60/2015 i 18/2016

Zakon o vlasništvu i drugim stvarnim pravima BD BiH, Službeni glasnik Brčko distrikta BiH, br. 11/2001, 8/2003, 40/2004 i 19/2007 


\section{Odluke sudova u BiH}

Odluka Ustavnog suda BiH AP-1086/04 od 02.12.2005.

Odluka Ustavnog suda BiH AP-1261/07 od 10.01.2008.

Odluka Ustavnog suda BiH AP-3381/14 od 23.01.2015.

Odluke Ustavnog suda BiH AP-1154/14 od 11.01.2017.

Odluka Ustavnog suda BiH AP-1872/20 od 23.06.2020.

Odluka Ustavnog suda BiH AP-4380/13 od 22.12.2016.

Odluka Ustavnog suda BiH AP-2734/15 od 14.10.2015.

Odluka Ustavnog suda BiH AP-423/15 od 14.10.2015.

Odluka Ustavnog suda BiH AP-4007/18 od 12.03.2019.

Odluka Ustavnog suda BiH AP-444/20 od 05.05.2021.

Odluka Vrhovnog suda Federacije BiH 28 O I 052479 16 Spp od 05.12.2016.

\section{Odluke Evropskog suda za ljudska prava}

Vaskrsić protiv Slovenije, Aplikacija br. 31371/12, Odluka od 25.04.2017.

Ljaskaj protiv Hrvatske, Aplikacija br. 58630/11, Odluka od 20.12.2016.

Pibernik protiv Hrvatske, Aplikacija br. 75139/01, Odluka od 04.03.2004.

Omerović protiv Hrvatske, Aplikacija br. 36071/03., Odluka od 01.06.2006.

EVT Company protiv Srbije, Aplikacija br. 3102/05., Odluka od 21.06.2007.

Bulović protiv Srbije, Aplikacija br. 14145/04, Odluka od 01.04.2008.

Atanasović i dr. protiv Makedonije, Aplikacija br. 13886/02., Odluka od 22.12.2005.

Jelčić protiv Bosne i Hercegovine, Aplikacija br. 41183/02, Odluka od 31.10.2006.

Muhović i Lekić i dr. protiv Bosne i Hercegovine, Aplikacija br. 4084l/13, Odluka od 15.09.2020.

Akeljić i ostali protiv Bosne i Hercegovine, Aplikacija br. 8039/19, Odluka od 13.10.2020.

Burmych protiv Ukrajine, Aplikacija br. 46852/13, Odluka od 12.10.2017. 


\section{Summary}

\section{Meliha Povlakić* \\ Tahir Herenda** \\ Nasir Muftić ${ }^{* * *}$}

\section{POSSIBILITIES OF THE ABUSE OF PROCEDURAL RIGHTS IN THE ENFORCEMENT PROCEDURE FOR THE SALE OF REAL ESTATE IN THE LAW OF BOSNIA AND HERZEGOVINA}

The primary goal of the reformed enforcement law in Bosnia and Herzegovina $(B \& H)$ is efficient compensation. However, many impediments exist. In this paper, the authors present some of the problems and potential abuses of procedural rights in the enforcement law of $B \& H$. Two instances of abuse of rights regarding real estate are presented, which can open the doorway to other abuses, as well. Also, the abuse of procedural rights in the enforcement procedure is seen as underexplored in legislation, doctrine and case law. The paper addresses similarities and differences between the entities' and the Brcko District legal systems regarding the presented abuses, as well as comparative law. It is focused on the analysis of legislation and the interpretation thereof in light of recent case law in $B \& H$ and problems arising from it. The identified problems often prevent the goal of the enforcement procedure from being fulfilled. The paper has two parts, each dealing with one instance of abuse. The first part concerns the engineering of the most favourable offer in the bidding. The second part concerns the problem of a fictional offer to purchase real estate in the bidding and the character of the deposit. The paper provides suggestions for amending legislation based on some good legal solutions in the region.

Keywords: enforcement procedure, abuse of rights, civil procedural law, public bidding, real estate enforcement

* Meliha Povlakić, Ph. D., Professor, Faculty of Law, University of Sarajevo, Obala Kulina bana 7, 71000 Sarajevo, Bosnia and Hercegovina; m.povlakic@pfsa.unsa.ba; ORCID ID: orcid.org/0000-0002-3735-7543

** Tahir Herenda, LL. M. (CEU), Assistant, Faculty of Law, University of Sarajevo, Obala Kulina bana 7, 71000 Sarajevo, Bosnia and Hercegovina; t.herenda@pfsa.unsa.ba; ORCID ID: orcid.org/0000-0001-7631-6827

*** Nasir Muftić, LL. M. (CEU), Assistant, Faculty of Law, University of Sarajevo, Obala Kulina bana 7, 71000 Sarajevo, Bosnia and Hercegovina; n.muftic@pfsa.unsa.ba; ORCID ID: orcid.org/0000-0002-5688-3565 